\title{
QUAL O LUGAR DO GÊNERO E DA DIVERSIDADE SEXUAL NA ESCOLA?
}

\author{
Flávio Pereira Camargo 4 \\ Rubenilson Pereira de Araújo5
}

\begin{abstract}
A(s) sexualidade(s) e o gênero estão, mais do que nunca, no centro dos discursos; estão a deixar o silêncio e o segredo e, por bem ou por mal, estão a provocar ruído, a fazer barulho e a fazer falar.
\end{abstract}

Guacira Lopes Louro

\section{Resumo}

Nosso objetivo, neste trabalho, é apresentar resultados parciais de um estudo de caso sobre práticas discursivas no ambiente escolar. Para nossas reflexões, neste artigo, delimitamos como recorte as entrevistas realizadas com as professoras e os professores, a diretora e a coordenação pedagógica, cujas informações obtidas nos levam ao questionamento sobre qual o lugar do gênero e da diversidade sexual na escola e quais as suas implicações sociais no cotidiano de alunas e alunos homossexuais, sobretudo o que se refere à homofobia na escola.

Palavras-chave: gênero; diversidade sexual; homofobia; educação.

\section{Abstract}

Our goal in this paper is to present partial results of a case study of discursive practices in the school environment. For our reflections in this article, as delimited cut out the interviews with the teachers, the educational director and co-ordination, with lead to information obtained in questioning about what the place of gender and sexual diversity in schools and what their implications students in the daily social and gay lesbian students, especially with regard to homophobia in schools.

Keywords: gender; sexual diversity; homophobia; education.

\section{Introdução}

Atualmente, estamos vivenciando um período de transição de valores e paradigmas em nossa sociedade, principalmente em relação ao paradigma educacional que tenta, de alguma forma, trazer para a escola discussões relacionadas às questões de gênero, de identidade, de sexualidade e étnico-racial, com o intuito de oferecer a uma demanda heterogênea

4 Doutor em Literatura pela UnB e Mestre em Estudos Literários pela UFG. Atualmente desenvolve pesquisa de Pós-Doutorado no Pós-Lit da UFMG. É professor Adjunto da UFT, atuando na graduação e no Programa de Pós-Graduação em Letras: Mestrado em Ensino de Língua e Literatura. Desenvolve e orienta pesquisas sobre questões relacionadas à narrativa brasileira contemporânea, aos estudos de gênero e sexualidades e suas interfaces com a educação. E-mail: camargolitera@uft.edu.br

5 Professor efetivo da rede pública estadual de ensino do Estado do Tocantins e do Instituto Tocantinense Presidente Antônio Carlos (ITPAC/Campus de Porto Nacional), e Mestrando em Letras: Ensino de Língua e Literatura na UFT. E-mail: rubenilsonpereira@gmail.com 
de alunos uma formação ampla, crítica, reflexiva e, principalmente, humanística, de modo a lhes possibilitar uma plena cidadania.

Neste novo contexto educacional, que envolve o processo de formação de nossos alunos, nosso interesse recai justamente sobre aquelas questões que envolvem gênero, diversidade sexual e o currículo escolar a partir de uma perspectiva do paradigma educacional emergente, dos estudos culturais e dos estudos de gênero. Em nossa trajetória docente, o que percebemos é certa ausência significativa nos currículos escolares referente a estas questões como se nossos alunos fossem todos heterossexuais e se adequassem perfeitamente às práticas discursivas de subjetivação, praticamente impostas por uma sociedade patriarcal e falocêntrica.

Dito isto, em nossa pesquisa optamos por um estudo de caso sobre as práticas discursivas de subjetivação no ambiente escolar. Como subsídio metodológico para a coleta dos dados, valemo-nos principalmente de entrevistas semi-estruturadas com alunas e alunos, professoras e professores, diretora e coordenação pedagógica da escola-campo, uma instituição pública estadual, situada em uma região periférica no município de Porto Nacional, no Estado do Tocantins. Segundo as informações obtidas na secretaria dessa Unidade Escolar, através do Planejamento Estratégico da Secretaria (PES), a escola-campo atende atualmente a Educação Básica, com aproximadamente 1.100 (Um mil e cem) alunos matriculados desde $01^{\circ}$ ano do Ensino Fundamental até a $3^{a}$ série do Ensino Médio.

Em nossa coleta de dados, entrevistamos, por um lado, a diretora geral da Unidade Escolar, a Orientadora Educacional, e uma amostragem de 05 (cinco) professores regentes de turma do $2^{\circ}$ ano do Ensino Fundamental até o Ensino Médio. Por outro lado, com o objetivo de analisar os discursos e saberes que são produzidos sobre as práticas de subjetivação no ambiente escolar, também entrevistamos uma amostragem de 10 (dez) alunos devidamente matriculados nas séries finais do Ensino Fundamental e Médio, ministrado pela referida escola, incluindo-se aí 02 (dois) alunos membros da liderança escolar (Grêmio Estudantil), 04 (quatro) alunos egressos, assumidamente homossexuais. Destes, 01 (um) concluiu o Ensino Médio e não prosseguiu em seus estudos, outro progrediu e se encontra no nível superior e 02 (dois) evadiram da escola antes de concluírem a Educação Básica.

Para nossas reflexões neste ensaio, delimitamos como recorte parte das entrevistas realizadas com a diretora, a orientadora educacional, e os professores da escola-campo. A partir dos dados obtidos, partimos de uma discussão sobre o paradigma educacional emergente e sua relação com os temas transversais, propostos pelos Parâmetros Curriculares Nacionais (doravante PCN's) no currículo escolar. Em seguida, passamos a uma reflexão sobre a escola como o espaço ideal para a equidade de gênero e para a(s) diversidade(s) sexual(is), procurando estabelecer uma relação entre as questões de gênero, de identidade e de sexualidade com o currículo escolar a partir dos estudos culturais e dos estudos de gênero, cuja ênfase recai na análise dos discursos dos/as professores/as acerca destas questões consideradas por muitos deles/as como tabus. 


\section{Enlaçando discursos sobre gênero e diversidade sexual na escola}

Durante nossa pesquisa, percebemos por meio das entrevistas semi -estruturadas com a diretora, a orientadora educacional, as professoras e os professores, e com os alunos (ingressos e egressos) da escola-campo que elegemos para realizar nossas investigações, discursos que nos remetem a uma representação e a uma construção de determinadas identidades de gênero e sexuais em detrimento de outras. São construções discursivas que nos revelam de modo sutil, em alguns casos, certo preconceito e discriminação em relação aos alunos que não se encaixam em uma matriz heteronormativa. Em outros, este discurso homofóbico é explícito em relação àqueles corpos indisciplinados que não se deixam moldar dentro de padrões preestabelecidos por uma norma que se quer homogênea e incontestável.

Nosso contato inicial foi com a diretora da escola que se mostrou bem receptiva à pesquisa e muito interessada nas questões a serem investigadas no contexto escolar. Posteriormente, entramos em contato com a profissional que exerce a função de orientadora educacional, que deve atender às seguintes exigências do quadro de pessoal da SEDUC: ser licenciada em Pedagogia, com habilitação específica em Orientação Educacional, além de possuir experiência de atuação na área, participar de cursos/capacitações a respeito de orientação escolar e cuidar dos problemas inerentes à disciplina dos alunos, comportamentos bio-psico-sociais de professores e alunos, envolvendo o relacionamento inter e intrapessoal. No primeiro dia de entrevista, os professores se encontravam reunidos para o planejamento quinzenal coletivo e foram escolhidos e encaminhados a nós pela orientadora educacional e pela diretora da escola.

As entrevistas foram organizadas em forma de questionário semi-estruturado de modo a possibilitar ao pesquisador e aos informantes da pesquisa uma possibilidade de diálogo sobre outras questões que pudessem surgir a partir daquelas norteadoras de nossa pesquisa.

A pergunta inicial foi se havia algum projeto, interdisciplinar ou não, em desenvolvimento na escola sobre questões relacionadas à sexualidade.

Eis as respostas que obtemos de nossos participantes:

Diretora: "Sim, o Projeto Saúde e Prevenção que enfoca muito mais as DST do que gênero ou orientação sexual". Orientadora Educacional: "O projeto que a escola desenvolve é o SPE que trabalha a temática da sexualida-

6 O Projeto "Saúde e Prevenção nas Escolas - uma visão humanística" (doravante SPE) foi idealizado pelos Ministérios de Saúde e de Educação destinado a adolescentes e jovens e, objetiva "auxiliá-los(as) no desenvolvimento de ações de formação para a promoção da saúde sexual e saúde reprodutiva, a partir do fortalecimento do debate e da participação juvenil" (Prefácio da Apostila de Metodologias do Projeto SPE, denominada "Adolescentes e Jovens para a Educação entre pares". Segundo orientações da Secretaria de Educação (SEDUC-TO), cada Unidade Escolar da rede pública deverá inseri-lo no Projeto Político Pedagógico (PPP) ações pontuais, envolvendo as temáticas da sexualidade (com ênfase em prevenção de DSTs e gravidez na adolescência) e uso de drogas ilícitas de acordo com as demandas apresentadas no contexto de cada escola. 
de com oficinas, protagonismo juvenil e bullying. Tudo ocorre aqui na escola com parcerias com profissionais da saúde e polícia comunitária. O projeto enfoca também a questão das drogas, o preconceito e as doenças tropicais.

Professor I (ministra aulas para uma turma do $2^{\circ}$ ano do Ensino Fundamental): "Eu não conheço".

Professora II (ministra a disciplina de Língua Portuguesa nas turmas de $6^{\circ}$ e $7^{\circ}$ ano do Ensino Fundamental e Filosofia/Sociologia nas três séries do Ensino Médio): "A escola em si mesma não aborda essa questão. Na prática pedagógica, trabalhamos de acordo com a necessidade do conteúdo programático. Exemplo: Corpo humano; textos, como bullying, respeito ao outro..." (pausa).

Professor III (ministra a disciplina de Educação Física nas séries do Ensino Fundamental e Médio): "Ha o projeto 'gravidez na adolescência'. Trabalhamos o mesmo de maneira interdisciplinar com parceria de universidades locais".

Professora IV (ministra as disciplinas de Língua Portuguesa e Ensino Religioso nas séries finais do Ensino Fundamental): "Há um projeto interdisciplinar sobre sexualidade (pausa), não lembro o nome, mas acho que é projeto "Valores", ele também aborda a sexualidade".

Professora $V$ (ministra aulas de Língua Portuguesa e Ciências no $4^{\circ}$ e $5^{\circ}$ ano do Ensino Fundamental): "Há um projeto ai chamado SPE e outro chamado "Valores". (Encerrou o assunto!) (Entrevista semi-estruturada realizada em 07 de dezembro de 2010).

A segunda pergunta foi sobre as metodologias adotadas pela escola em relação aos temas transversais propostos pelos PCN's: "Como a escola trabalha com os temas transversais relacionados à sexualidade, ao gênero, à orientação sexual e às doenças sexualmente transmissíveis?" As respostas obtidas por nós de nossos participantes assemelham-se expressivamente às dadas à questão anterior.

Nestas construções discursivas de nossos participantes é possível observarmos que a temática da orientação sexual está presente na prática pedagógica, porém relacionada apenas à prevenção das doenças sexualmente transmissiveis ou através de uma abordagem biológica do sexo, que advém justamente de uma parceria com os profissionais da saúde, incluindo-se aí os acadêmicos dos cursos de graduação também em saúde, os quais ministram palestras sobre as doenças sexualmente transmissíveis. Além disso, tal fato nos revela que as questões propostas pelos PCN's, que deveriam ser abordadas de forma ampla, inter e transdisciplinar, permanecem restritas somente ao âmbito das ciências biológicas.

Outro fator percebido em tais discursos é que há dúvidas em relação aos conceitos de interdisciplinaridade quando se menciona a visão interdisciplinar, confundindo-a com a pluridisciplinaridade, promovida através de parcerias com outro segmento de profissionais. Além disso, tanto os professores quanto os alunos foram unânimes em afirmar que a temática é abordada somente quando está prevista no conteúdo programático curricular, de 
modo que não há efetivamente uma prática pedagógica que se volte para uma perspectiva crítica em relação a estes temas tão caros a nossas alunas e alunos em processo de formação.

Estes dados confirmam ainda o que já constataram Zulmira Borges e Dagmar Meyer em suas pesquisas sobre os limites e as possibilidades de práticas educativas na redução da vulnerabilidade à violência e da homofobia no contexto escolar:

Em 1995, o governo federal anunciou os PCN's (BRASIL, 1998), entre os quais aparecia a determinação de que a sexualidade fosse tratada como tema transversal. A ideia era de que diversas disciplinas integrassem o assunto de maneira articulada com outros temas. A abordagem, porém, baseada em uma visão biologizante do sexo ainda predomina, e a discussão sobre a diversidade de orientações sexuais é ainda marginal ou ausente (2008, p. 61-62).

A terceira pergunta da entrevista semi-estruturada foi a seguinte: "Há algum curso de formação continuada ou de capacitação sobre gênero e sexualidade na escola ofertado pela DRE ou outro órgão/instituição em parceria com o Estado?"

Obtivemos as seguintes respostas:

Diretora: "Não, não temos nenhum curso ou capacitação específica sobre gênero e sexualidade" (foi bem objetiva enfática).

Orientadora Educacional: "Sim, há um curso de formação continuada do MEC e multiplicado por assessores de currículo da disciplina de Biologia da DRE chamado SPE - uma visão humanística com oficinas pedagógicas e palestras ${ }^{7 "}$.

Professor I e II: "Ainda não participamos de nenhum curso nesse sentido, porém vemos a necessidade de abordar essa questão em sala de aula, mas para isso precisamos de um preparo" (ambos solicitaram para ficar juntos a partir desse momento da entrevista).

Professor III: "Eu nunca tive nenhum curso nessa área, desde que assumi o magistério".

Professora IV: "Não conheço e nunca participei"

Professora V: "Não" (Entrevista semi-estruturada realizada em 07 de dezembro de 2010).

Nestes discursos, observamos de forma explícita uma contradição entre o discurso da profissional ocupante da função de Orientadora Educacional com o da diretora e demais docentes. Tal fato provavelmente ocorre porque é aquela profissional que participa das capacitações periódicas do curso SPE ${ }^{8}$ em nível da Diretoria Regional de Ensino (DRE). No entanto,

7 A profissional que exerce a função de Orientadora Educacional no quadro de pessoal da escola participa de capacitações esporádicas na Diretoria Regional de Ensino (DRE) e é responsável pela multiplicação/disseminação do conteúdo da formação no âmbito da Unidade Escolar.

8 Segundo informações obtidas na DRE, as capacitações do curso SPE ocorrem bimestralmente com o representante de cada escola estadual (no caso, a orientadora educacional). 
considerando-se as várias atribuições que são conferidas ao referido cargo, como, por exemplo, em única manhã em que estivemos presentes na escola-campo a servidora cuidou de problemas inerentes à evasão escolar, da indisciplina de alunos ocorrida em sala de aula, prestou atendimento à professora no momento de seu planejamento quinzenal e preenchimento das fichas individuais de rendimento dos alunos, confeccionou cartazes para ambientação das salas de aula, entre outras atividades.

Ao questioná-la sobre a efetividade da disseminação e/ou multiplicação do material trazido do curso SPE com os professores, ela confirmou que é humanamente impossivel encontrar tempo disponível para realizar as oficinas e a socialização da leitura desses textos com os professores e alunos, mesmo que haja um acervo significativo de material para leitura e aplicação de oficinas. Infelizmente, o acúmulo de atribuições destinadas à profissional tolhe-lhe as possibilidades de efetivar em sua prática pedagógica parte do conhecimento que adquire nos cursos de capacitação, assim como a impossibilita de compartilhá-lo com os seus pares.

Em relação ao projeto SPE, encaminhado para ser trabalhado na escola, percebemos que o mesmo não consegue a adesão de todos os docentes, inclusive alguns profissionais nem sabem de sua existência. Além disso, este projeto, desde a sua gênese na parceria entre o Ministério da Educação e o da Saúde, demonstra que, "embora venha sendo paulatinamente ressignificado, o termo [homofobia] possui ainda fortes traços do discurso clínico e medicalizante que the deu origem" (JUNQUEIRA, 2007, p. 3-4).

Em muitos discursos e práticas pedagógicas ainda prevalece uma concepção retrógrada que concebe a homossexualidade a partir de uma perspectiva patológica, tratando-a como "problemas de desvios sexuais" e como uma espécie de "doença", passível, portanto, de cura e de tratamento médico. Neste sentido, "a escola passa a ser tida como um espaço de intervenção preventiva da medicina higiênica, devendo cuidar da sexualidade de crianças e adolescentes a fim de produzir comportamentos normais" (ALTMMAN, 2001, p. 575), como se o sujeito que é homossexual fosse um "anormal", justamente por que não se encaixa em um dado padrão de masculinidade praticamente imposto aos nossos alunos nas práticas discursivas de subjetivação por parte de nossos professores. Percebemos, pois, que há alguns progressos expressivos no tocante às questões de gênero, identidade e sexualidade no âmbito da educação, mas, infelizmente, estes avanços ainda são insipientes.

Esses dados nos revelam de formas distintas a necessidade de uma ênfase maior em políticas públicas de educação que abordem tais temáticas no processo de formação de nossos alunos, assim como demonstra que também é preciso rever o papel e a função da universidade na formação docente - inicial e continuada - daqueles profissionais que serão responsáveis pela formação de futuros cidadãos. Além disso, percebemos nos discursos dos participantes que ainda é necessária uma estrutura de assessoria técnico-pedagógica em nível de MEC-SEDUC-DRE-Escola para uma plena efetivação dos cursos de capacitação que são oferecidos aos professores. 
De acordo com Seffner, para que a escola se torne, de fato, um espaço para a equidade de gênero, com respeito e valorização da diversidade sexual, seria necessária a "construção de um ambiente de acolhida para com as diferentes formas de viver a sexualidade constar claramente nos documentos oficiais da escola, quais sejam, o Projeto Político Pedagógico (PPP), o Regimento Escolar, os Planos de Ensino de Estudo etc." (2009, p. 135). Entretanto, percebemos que a situação é complexa e envolve toda uma conjuntura de agentes educacionais desde a assessoria técnica até a escola onde, de fato, se efetiva a prática educacional.

Dando continuidade às nossas reflexões sobre a gênese de idealização doprojetoSPE, averificação desuainoperâncianoâmbito dapráticaeducativa da escola-campo e as políticas públicas educacionais voltadas para programar ações efetivas na prática docente em relação às questões de gênero e de diversidades sexuais, percebemos que as relações de poder estabelecidas funcionam como controle por parte do governo, como aponta a teoria de Foucault. Também concordamos que este fato reforça ainda mais as crenças de uma sociedade heteronormativa, fomentando "a política sexual [fundamentada] num conjunto de pressupostos arraigados da tradição sexual: o sexo como perigo e ameaça, mais do que como oportunidade" (LOURO, 2010, p. 130).

A professora II, informante da pesquisa, ao ser interpelada na quarta pergunta se já teve ou tem algum/a aluno/a homossexual ou lésbica e caso a resposta fosse afirmativa, relatasse como era/é o convívio com os outros colegas no ambiente escolar, deu-nos a seguinte resposta:

Além de alunos, já tive colegas de trabalho lésbicas, convivemos harmonicamente, o fato mais marcante foi de uma colega que manteve um relacionamento com outra. (risos). Tenho também um aluno no $7^{\circ}$ ano que demonstra trejeitos, convive bem com os colegas, mas muitos brincam com ele e o chamam de "florzinha", eu levo isso na normalidade, digo-Ihe para ser macho. Em outros, eu também percebo aparência, mas geralmente são mais discretos (Entrevista semi-estruturada com a Professora II em 06 de dezembro de 2010, grifos nossos).

Esta construção discursiva revela, em um primeiro momento, a possibilidade de uma convivência harmoniosa entre a participante, as colegas de trabalho lésbicas e os demais professores. Harmonia estabelecida desde que a fronteira entre os limites permaneça clara e muito bem estabelecida, pois a partir do momento em que duas das professoras lésbicas passam a se relacionar afetivamente, o convívio harmônico se quebra, pois se trata de um relacionamento não convencional, que fere de morte os valores tradicionais do conceito de família que temos em nossa sociedade. Veja-se, por exemplo, o riso irônico da participante quando se refere à relação homoafetiva entre as colegas de trabalho.

Em um segundo momento, essa mesma convivência que é considerada harmônica pela professora ocorre entre os alunos considerados "nor- 
mais", ou seja, heterossexuais, e aqueles que fogem ao padrão preestabelecido, os "anormais", os que são homossexuais, principalmente aqueles que estão se assumindo publicamente, demonstrando através de trejeitos femininos que não se encaixam nos padrões de masculinidade, mas no de feminilidade. É justamente em decorrência deste descompasso entre sexo e gênero que o referido aluno pode ser discriminado pelos outros, que o chamam de "florzinha". Esta adjetivação é extremamente pejorativa e preconceituosa denegrindo a imagem do outro e sua identidade. Neste caso, o discurso da educadora, uma profissional responsável pela formação de nossos alunos, simplesmente vê este ato com total normalidade, quando é, na verdade, uma agressão verbal, passível de punição ou de uma reeducação de valores humanos e éticos.

Em seguida, em um terceiro momento, a fala da professora reproduz um discurso que está arraigado em nossa cultura, o de que meninas devem ser educadas para exercerem o papel ou a função tradicionalmente destinada às mulheres, e os meninos para serem machos, viris, fortes. Esta construção discursiva revela em suas entrelinhas uma homofobia explícita em relação ao aluno que apresenta certos trejeitos, acatando como normais as piadas e as chacotas dos colegas, reforçando o discurso machista de que o aluno "deve ser macho" (sic). Além disso, também percebemos que em relação aos outros alunos que aparentam ser homossexuais, mas que se mantêm discretos, "dentro do armário", permanece aquele contrato harmônico, contudo, seus limites são muito tênues e nunca sabemos ao certo quando eles serão rompidos.

Considerando a análise do discurso dessa participante, que endossa outros discursos, percebemos que, de fato, a homofobia é (re)produzida no ambiente escolar. Trata-se, na verdade, de uma espécie de uma homofobia que se torna "consentida e ensinada na escola, [pois] a homofobia expressa-se pelo desprezo, pelo afastamento, pela imposição do ridículo" (LOURO, 2010, p. 29). É justamente esta exposição ao ridículo que ocorre no contexto escolar de nossa escola-campo, é como se fosse um ato punitivo por o aluno ser homossexual, então ele pode ser exposto à injúria e ser desprezado pelos colegas. Trata-se de uma prática de silenciamento ou de negação, por parte da escola, de uma identidade e de uma sexualidade que já nasce estigmatizada em nosso meio social.

A consequência desta prática pedagógica para os alunos gays ou lésbicas é que eles passam a si considerarem "marcados como corpos -e sujeitos - ilegítimos, imorais ou patológicos" (LOURO, 2008b, p. 82), contribuindo, de forma negativa, para a constituição das subjetividades desses alunos. Em relação à injúria e suas repercussões na vida desses sujeitos, Flávio Pereira Camargo afirma que

[a] injúria, ao se inscrever na memória e no corpo dos indivíduos, passa a fazer parte da constituição da própria personalidade, da própria subjetividade daqueles sujeitos que outrora experimentaram na pele as dores, as mágoas e os sofrimentos advindos de agressões verbais e/ou físicas. São memórias amargas que estão in- 
crustadas em nosso corpo e em nossa mente, que nos fazem recordar, em distintos espaços de sociabilidade, que devemos, de certa forma, dissimular nossa identidade através e por meio de ações e de atitudes corporais que não denunciem nossa identidade homossexual, de modo a evitar possíveis agressões verbais e, até mesmo, físicas (2010, p. 79).

Dito isto, podemos imaginar e/ou visualizar a dimensão da gravidade de determinadas atitudes tomadas por professores e demais agentes educacionais em nossa prática pedagógica frente à homossexualidade. Ainda nesse sentido, a quinta pergunta durante a entrevista semi-estruturada foi a seguinte: "Qual o posicionamento dos professores e da coordenação pedagógica diante dos alunos homossexuais que sofrem algum tipo de preconceito ou discriminação na escola?" Nesse item alguns professores afirmaram que encaminham o caso para a coordenação ou direção, assim, procuramos dar visibilidade à resposta da diretora:

Muitos professores fingem que não vêem o caso, outros
procuram os coordenadores, não se preocupam, não
leva o caso a sério. Há casos em que os professores en-
caminham o aluno para a coordenação; percebe-se
muito medo de se comprometerem (Entrevista semi-es-
truturada com a diretora da escola em 06 de dezembro
de 2010).

De modo geral, notamos que as questões que envolvem a sexualidade e gênero ainda são consideradas tabus e/ou marcadas pelo medo ou até mesmo certo despreparo por parte dos professores que, em alguns casos, não sabem sequer a diferença entre gênero e sexo e suas implicações na constituição das subjetividades de seus alunos. Este discurso revela não somente um despreparo por parte dos professores, mas, principalmente, o medo em tocar em um assunto tido como tabu, algo que simplesmente pode abalar todos os valores socioculturais e principalmente religiosos de alguns educadores.

É justamente por isso que muitos tapam os olhos, fingem que não há casos de violência verbal e física em relação a certos alunos, pois é mais fácil encaminhar o "problema" para a coordenação pedagógica ou a direção do que tentar, de algum modo, contribuir para sanar as polêmicas geradas a partir dele.

Não podemos mais ignorar o fato de que as questões referentes às sexualidades e aos gêneros são latentes no ambiente escolar. Durante nossa estadia na escola-campo, ao analisarmos a estrutura física de alguns de seus espaços, verificamos a presença de frases e/ou rabiscos em paredes e portas que reproduzem certos discursos discriminatórios ou preconceituosos, além, é claro, de outros discursos com fundo erótico que aguçam a libido do jovem leitor. Durante o intervalo entre as aulas - denominado como recreio - também pudemos ouvir e ver certas brincadeiras e, até mesmo, algumas piadinhas pejorativas em relação a certos alunos afeminados. São discursos 
que remetem de modo explícito à sexualidade desses jovens adolescentes que se encontram em processo de descoberta do prazer, do desejo, e do componente erótico, constitutivo de cada um de nós, enquanto ser humano.

É justamente por isso que podemos afirmar, na esteira de Guacira Lopes Louro, que

[as] questões referentes à sexualidade estão, queira-se ou não, na escola. Elas fazem parte das conversas dos/ as estudantes, elas estão nos grafites dos banheiros, nas piadas e brincadeiras, nas aproximações afetivas, nos namoros e não apenas aí, elas estão também de fato nas salas de aula - assumidamente ou não -, nas falas e atitudes das professoras, dos professores e estudantes (2008a, p. 131, grifo da autora).

Nesse contexto escolar em que prevalece o silenciamento ou a negação de determinadas identidades e sexualidades, apontamos o medo, que é, para nós, um dos principais pilares dessa prática de silenciamento e de negação. Trata-se de um medo de ferir de morte um conceito unilateral de família e de relacionamentos afetivos que ainda estão presentes e arraigados em nosso imaginário - individual e coletivo. De modo geral, percebemos que há uma reprodução desse imaginário, dificultando significativamente a abordagem sobre as sexualidades, principalmente sobre a homossexualidade, na sala de aula. Isso ocorre porque, afinal, "para muitos adultos, esses sempre foram temas que se conversavam em voz baixa, com reservas e com poucas pessoas. O silêncio, o segredo e a discrição eram os comportamentos adequados com a sexualidade" (LOURO, 2008a, 133).

A partir de nossos dados, compreendemos que o espaço escolar ainda não está plenamente aberto à diversidade, de tal modo que em pleno início do século XXI temos "uma instituição [escolar] que resiste aos novos tempos, às novas reflexões que se fazem prementes, e opta por permanecer em uma posição aparentemente desvinculada dessas discussões", mas nós sabemos que esta suposta neutralidade é impossível "já que elas permeiam todos os espaços e relações sociais" (FACCO, 2009, p. 22), mesmo porque o silêncio também é uma forma de exclusão do outro e de seu discurso.

Na sexta pergunta, realizamos o seguinte questionamento: "Há registros de homofobia dentro da escola? Há/houve agressões físicas ou somente verbais? Em caso afirmativo, como a escola tem procurado resolver essa questão?"

Eis as respostas obtidas:

Diretora: "Não há registros de agressão física, mas há muitos casos de agressão verbal com palavras difamatórias, o único caso que houve agressão física partiu do aluno homossexual agredido. Nesses casos, tomamos providências cabíveis, como aconselhamento, advertência e outros".

Orientadora Educacional: "Sim; quando isso ocorre, aplicamos advertência escrita, solicitando a presença dos pais e/ou responsáveis. Nunca houve agressão física, 
apenas verbal".

Professores I e II: "Olha, agressão física nunca houve, achamos o clima pacífico em relação à questão da homofobia, não há discriminação na escola".

Professor III: "Não há casos de agressão física, apenas verbal".

Professora IV: "Há registros de agressão verbal apenas, esses problemas são encaminhados para a orientadora resolver".

Professora V: "Não tenho conhecimento de nenhum caso" (Entrevista semi-estruturada realizada em 07 de dezembro de 2010, ênfase dada pelos participantes).

Em relação à homofobia no ambiente escolar, 04 (quatro) de nossos participantes afirmaram que há registros de agressão verbal diariamente e, em alguns casos, até mesmo física. O que ocorre é que, infelizmente, alguns educadores não vêem esta prática como um ato de violência, que pode, inclusive, deixar marcas mais profundas do que as físicas. Há ainda valorização da agressão física em detrimento da verbal, como podemos notar no modalizador verbal "apenas", enfatizado nos discursos da orientadora educacional, do professor III e da professora IV.

Além disso, estes discursos que não reconhecem a agressão física como uma injúria, movida pelo preconceito e pela discriminação, podem levar a sérias consequências, pois ela não é, em hipótese nenhuma, "menos grave e danosa" (RIOS, 2009, p. 72), podendo, inclusive, provocar repercussões que podem de algum modo interferir negativamente em toda a vida de suas vítimas. Também observamos certa unanimidade nos discursos ao considerar a agressão verbal como algo normal, além de a escola, por meio da direção e da coordenação (orientadora educacional), ser a responsável pela punição e pela manutenção da ordem, ou seja, neste caso, aqueles estudantes considerados "anormais" se encontram sob olhares atentos e vigilantes, pois "as políticas curriculares são, então, alvo da sua atenção, na tentativa de regular e orientar crianças e jovens dentro dos padrões que consideram moralmente sãos" (LOURO, 2008a, p.130).

Inclusive os discursos dos professores I e I| demonstram que o clima na escola é pacífico e que não há casos de discriminação. A professora IV também endossa este mesmo posicionamento ao afirmar categoricamente que desconhece qualquer caso de homofobia. Ora, há nestes discursos uma contradição latente com os discursos de outros professores e profissionais da escola, explicitando que o fato de um aluno passar por um processo público de desprezo e de exposição ao ridículo, quando é exposto às injúrias individuais ou coletivas por parte dos colegas de sala de aula ou durante os intervalos para recreação, é desconsiderado como prática de violência. Gostaríamos de lembrar que a violência se materializa de diversas formas, inclusive a violência simbólica é praticada por aqueles profissionais que simplesmente optam por se omitirem.

Em seguida, passamos à sétima pergunta de nossa entrevista: "Que dificuldades você encontra/ou para trabalhar com alunos que são homossexuais?" 
Esta questão exigiu de nossos informantes uma resposta que envolveria um caráter mais subjetivo, uma vez que teriam que relatar alguma experiência vivenciada em sua prática pedagógica. No entanto, a maioria foi categórica ao afirmar que ainda não tiveram alunos homossexuais e/ou se tiveram ou tem, ainda não perceberam. Este fato nos leva à conclusão de que há certas incongruências em seus discursos, pois em momentos anteriores verificamos que há, na escola, alunos homossexuais, inclusive um deles foi aluno de uma de nossas professoras informantes.

Entre as respostas dadas a esse questionamento, fizemos nosso recorte do discurso da diretora, da orientadora educacional e da professora IV, por julgarmos mais expressivas à nossa pesquisa:

Diretora: "Primeiro, eu acho que (pausa...) é ele mesmo se aceitar, a questão é melindrosa, como vou abordar o assunto [da homossexualidade] se ele não se aceita? Percebo ainda a falta de preparo dos professores para trabalharem isso porque eles não têm esse convívio".

Orientadora Educacional: "Não tenho dificuldades, trabalho de maneira igual, o problema ocorre é na questão da auto-aceitação e o conflito familiar".

Professora IV: "Eu já trabalhei com alunos que nós da escola deduzíamos que ele é, mas torna-se muito difícil porque ele não se aceitou, procuro tratá-lo como hétero, porque ele não me dá liberdade para conversar sobre isso. Agora, quando um gay me procurou para falar sobre o assunto, aconselhei-lhe a se assumi. Ainda acho que a maior dificuldade é a auto-aceitação" (Entrevista semi-estruturada realizada em 07 de dezembro de 2010).

Nestes discursos, o que nos chama a atenção é o fato de que há um despreparo que é latente na formação dos professores para lidarem com a questão da homossexualidade. Inclusive há afirmações de que esta carência de conhecimento advém de uma ausência de convívio com sujeitos homossexuais, como se esta convivência fosse necessária, vital e substancial para compreender melhor o outro e a constituição de sua identidade.

Outro aspecto latente diz respeito à questão da auto-aceitação ou do ato de se assumir como gay publicamente. Ora, não é extremamente necessário que haja na escola alunos gays - masculinos ou femininos - ou que os alunos homossexuais se assumam para que os professores trabalhem com esta questão. Trata-se de um assunto que envolve valores humanos, éticos e morais de respeito ao outro, à alteridade, de dignidade humana, que não é discutido no ambiente escolar, que deveria, em tese, propiciar uma formação humanística aos nossos alunos.

Em relação a esse processo de sair ou não do armário, ou do ato de se assumir publicamente como homossexual, Fabrício Viana afirma que

[a] alguns anos atrás militantes gays, nos EUA, criaram a expressão coming out ou simplesmente outing para designar o processo das pessoas assumirem abertamente sua homossexualidade. No Brasil, a expressão mais próxima, conhecida e utilizada é "saindo do armário", inclu- 
ída até nas últimas edições do Dicionário Aurélio. Sabemos que armário é um móvel que temos dentro de casa com a possibilidade de trancar suas portas e evitar que qualquer pessoa tenha acesso ao seu conteúdo. Assim, o armário torna-se um símbolo importantíssimo para representar o local de nossa personalidade em que escondemos e trancamos - para que os outros não possam ver - nossos desejos proibidos. Nossos desejos homossexuais (2010, p. 59).

Sair ou não do armário é, portanto, uma difícil decisão para muitos homossexuais. Este fato se acentua principalmente quando se trata de pessoas ainda em formação, como é o caso de nossos jovens alunos em idade escolar. Neste sentido, é importante considerar que "entre os processos internos, o medo é um dos principais fatores que faz com que os desejos homossexuais sejam jogados e trancados no armário" (VIANA, 2010, p. 60).

Diante desta realidade, segundo Didier Eribon, "não deve existir gay, por mais 'aberto' que seja, que não tenha um dia ou outro transigido com a questão do armário: por isso é que a 'saída do armário' não é um gesto único, unívoco [...] é uma espécie de 'ideal regulador" (2008, p. 141). Este 'ideal regulador' é estipulado e estabelecido pelo meio sociocultural e às diversas circunstâncias às quais o sujeito é submetido, pois "ninguém está simplesmente fora ou dentro, mas sempre, ao mesmo tempo, fora e dentro, mais ou menos fora ou mais ou menos dentro [...] o 'armário' é sempre suscetível de ser um 'segredo público'". E isso ocorre pelo fato de que "a esfera pública exige que se use a máscara da heterossexualidade e que se esconda a identidade 'anormal'; [pois] a vida pública está fundamentalmente ligada à heterossexualidade e exclui o que dela se afasta" (ERIBON, 2008, 129).

Este ato de se esconder no armário ou dele sair pode se estender por toda a vida do indivíduo, pois

[a] maioria dos sujeitos homossexuais opta, por questões sociais, políticas e até econômicas, por se manterem "dentro do armário", ou seja, preferem não assumir as suas identidades de gênero e sexual em público por motivos diversos. Em alguns casos, esses sujeitos mantêm-se no armário por causa do emprego, da família, da violência física e simbólica praticada contra os homossexuais, por causa do estereótipo, das ofensivas, das injúrias, das críticas, entre outras questões (CAMARGO, 2010, p. 78).

Enfim, diante dessas construções discursivas nos perguntamos: que formação é esta que a escola ou até mesmo a universidade dá aos nossos jovens? Uma formação que não Ihes possibilita uma compreensão ampla e consciente em relação aos valores que constituem diferentes culturas, identidades e sexualidades. Na verdade, essa omissão por parte de nossos educadores recai novamente naquela premissa anterior que já havíamos discutido ao analisar outro recorte, o conflito entre escola e família. Esta ainda tem como paradigma aquela percepção de uma família nuclear constituída única e exclusivamente por duas pessoas de sexo opostos, juntamente 
com seus filhos, seguindo todos os princípios de um casamento dentro dos padrões aceitáveis de nossa sociedade.

Outro fato interessante percebido na pesquisa é que $100 \%$ dos professores informantes, incluindo-se a direção e o serviço de orientação educacional, mostraram-se bastante confusos ao conceituar a noção de gênero, sexualidade e identidade proposta na questão oito. Alguns solicitaram ajuda nos conceitos, outros mudaram de assunto e alguns disseram que preferiam não responder à pergunta feita, conforme verificamos no seguinte recorte: "(Grande pausa...) Ah!... Seriam conceitos? O gênero seria o tradicional masculino e feminino? A identidade seria além dessa questão? Muitas pessoas não seguem essa identidade e o sexo vai além disso..." (Entrevista semi-estruturada com a diretora da escola em 06 de dezembro de 2010).

A análise dos discursos de nossas entrevistas nos permite afirmar, sem sombra de dúvida, que há certo despreparo teórico-crítico e até mesmo prático por parte dos docentes para abordarem a temática de gênero e da diversidade sexual no contexto da sala de aula. Há, inclusive, uma tentativa de omitir a questão ou silenciá-la, o que acaba por provocar equívocos e armadilhas na articulação entre gênero, identidade, diversidade sexual e políticas de inclusão escolar na contemporaneidade.

Esta dura realidade nos leva a refletir sobre a necessidade de se repensar a efetividade das práticas das políticas públicas em educação no tocante à formação de docentes aptos a lidarem com as demandas atuais, que aprendam de fato não apenas a tolerar, mas "respeitar a diferença porque sob a aparente diferença há uma mesma humanidade" (SILVA, 2000, p. 89). Além disso, há a necessidade de uma reflexão sobre o aperfeiçoamento da prática pedagógica dos professores em exercício, promovendo uma formação continuada voltada para as questões de gênero e sexualidade na escola, que poderia possibilitar a garantia à plena cidadania por parte daqueles alunos marginalizados social e culturalmente em nossa sociedade.

O papel da universidade na formação inicial e continuada dos docentes aptos a atuarem na educação básica entra nessa problemática, pois "os cursos de licenciatura insistem em ensinar teorias obsoletas, que se mantém nos currículos graças ao prestígio acadêmico associado a elas, mas que pouco têm a ver com a problemática educacional brasileira" (D'AMBRÓsIO, 1999, p. 82). Para tanto, seria eficaz uma prática orientada para ações efetivas de inclusão da diversidade sexual em nossas escolas:

As questões que envolvem a diversidade sexual são complexas e exigem estudo por parte dos professores. Devemos lutar para ter acesso a materiais pedagógicos adequados, a cursos de formação, a participação em eventos que discutam os temas da sexualidade. Não devemos abordar nenhum tema de forma improvisada na escola. Escola é lugar de aprendizagens, e isto se faz de forma planejada (SEFFNER, 2009, p. 136).

A nona questão de nossa entrevista remete justamente a uma perspectiva conceitual: "Você já trabalhou alguma vez com as noções de gê- 
nero, sexualidade e identidade em sala de aula? Em caso afirmativo, que metodologias, suportes e materiais foram utilizados?"

As respostas obtidas, de modo geral, foram evasivas e algumas se voltaram para uma visão biológica do sexo. Outros assumiram não abordar essa questão, como verificamos na resposta da professora IV:

Trabalho a sexualidade usando filmes explicativos; não é fácil, eu tomo muito cuidado para não gerar conflito com a família, sempre só trabalho na questão da prevenção com o uso do preservativo; temos que ter muito cuidado com o que falamos. Dois assuntos delicados que eu acho é a sexualidade e o Ensino Religioso porque tenho medo de não ajudar e sim atrapalhar (Entrevista semi-estruturada com a Professora IV em 07 de dezembro de 2010).

Novamente, os discursos que obtemos a partir de nosso questionamento expõem a fragilidade de nossos educadores em relação a conceitos que seriam básicos e norteadores de uma prática pedagógica mais eficaz em sala de aula em relação a uma abordagem de gênero e sexualidades. No caso dessa informante, ela afirma que se vale do suporte filme para abordar algumas questões, entre elas, a da reprodução humana, a prevenção de doenças sexualmente transmissíveis e a prevenção da gravidez no período da adolescência por meio de preservativos. Instigada por nós sobre a opção pelo suporte fílmico, a professora disse que o utiliza por se tratarem de filmes bem didáticos e também porque o filme fala por si só, evitando comentários aprofundados dela posteriormente, o que explicita mais uma vez a dificuldade dos professores para abordarem e até mesmo estabelecerem uma discussão sobre determinados temas que podem entrar em conflito com seus valores sociais e religiosos. A propósito, ela afirma categoricamente que sexualidade e ensino religioso são áreas auspiciosas que podem, inclusive, gerar algum conflito com a família dos alunos. Percebemos, portanto, um discurso 'fortemente 'atravessado' por escolhas morais e religiosas, [uma vez que] o tratamento da sexualidade nas salas de aula geralmente mobiliza uma série de dualismos: saudável/doentio, normal/anormal (ou desviante), heterossexual/homossexual, próprio/impróprio, benéfico/nocivo, etc." (LOURO, 2008a, p. 133).

Apreendemos ainda, no discurso dessa professora, a insegurança e a dúvida que permeiam a sua prática docente, como se a mesma estivesse na sala de aula "pisando em areia movediça". Apesar de ela acreditar que a temática da sexualidade e da disciplina de Ensino Religioso são áreas delicadas, contraditoriamente, ela se encontrava responsável, à época da entrevista, por uma carga-horária extensa deste último componente curricular.

Notamos, também, que em seu discurso transparece certa sinceridade em relação à fragilidade atual em que se encontra a função docente, além de ela mesma estar visivelmente cansada, abatida e meio desnorteada, como se fosse um produto do sistema vigente, uma vez que "os corpos docentes estão submetidos a um processo similar de disciplinamento, do- 
mesticação e sujeição. A separação entre mente e corpo - central ao processo educacional e ao currículo - implica uma negação, um ocultamento do corpo docente, um processo de descorporização e desencantamento" (SILVA, 2011 , p. 197).

No caso de nossa informante, ela demonstra claramente seu desencanto com a educação, uma professora de certa forma domesticada e disciplinada dentro de certos padrões morais e sociais, considerando-se ainda o seu processo de formação no qual, sem sombra de dúvidas, não deve ter ocorrido discussões sobre gênero e sexualidade na educação, principalmente porque este campo de pesquisa é recente em nossas academias e nos cursos de formação de professores, o que nos remete àquelas considerações de Guacira Lopes Louro sobre "professores e professoras - [que] como qualquer outro grupo social - foram e são objeto de representações" (2008a, p. 99).

Além disso, a autora resgata a trajetória histórica de femininilização do trabalho docente no Brasil para demonstrar que, nas representações sociais das professoras, nas quais se insere nossa informante, podemos observar que "elas foram muito mais objetos do que sujeito dessas representações" (LOURO, 2008a, p. 103), uma vez que os discursos representativos no meio social foram construídos pelos homens (legisladores, religiosos, pais, médicos, etc.), somando-se à ideia de que em tal ofício "combinam-se elementos religiosos e "atributos" femininos, construindo o magistério como uma atividade que implica doação, dedicação, amor, vigilância" (LOURO, 2008a, p. 103-104), consequentemente, percebemos, através de nossa informante, que tais formas tradicionais de práticas discursivas ainda não foram "completamente superadas ou apagadas" (LOURO, 2008a, p. 108).

Os resquícios dessas práticas discursivas ainda prevalecem em nosso meio em constantes lutas de poder com novos discursos advindos do paradigma educacional emergente. São "práticas e representações conflitantes e contraditórias [que] coexistem, hoje e sempre, provocando divisões e impasses", consequentemente, muitas professoras e professores sofrem esses impactos em nossas salas de aula, pois nossas identidades não são fixas, pelo contrário, são instáveis: "essa aparente instabilidade e fluidez afeta, também, os próprios sujeitos, fazendo com que, muitas vezes, eles se percebam de algum modo divididos e contraditórios" (LOURO, 2008a, p. 109).

Como resultado direto dessa "crise de identidade contemporânea", que está intimamente relacionada àquela cisão e instabilidade do sujeito -professor, temos presenciado tanto uma relação de embate por parte do professor em relação a determinados assuntos ou temas considerados como tabus, quanto um alto índice de licenças médicas dos docentes para tratamento de doenças psicossomáticas, conforme dados obtidos no setor de recursos humanos da Diretoria Regional de Ensino de Porto Nacional/TO, além da falta de interesse de jovens pelos cursos de licenciatura, que têm como objetivo formar professores para atuarem na Educação Básica. 


\section{Considerações finais}

Atualmente, a escola pública brasileira, e, em especial, a função docente, passa por uma acentuada crise de discursos contraditórios e oscilantes, entre eles, encontra-se a difícil tarefa em saber como lidar com as questões de gênero e sexualidades na escola e com os próprios alunos que se vêem marginalizados no próprio espaço escolar, sem o pleno direito à cidadania. Nesse sentido, tanto a escola, enquanto instituição social, quanto as práticas discursivas

[...] não somente "fabricam" os sujeitos como também são, elas próprias, produzidas (ou engendradas) por representações de gênero, bem como por representações étnicas, sexuais, de classe, etc. De certo modo poderíamos dizer que essas instituições têm gênero, classe, raça. Sendo assim, qual o lugar do gênero na escola? (LOURO, 2008a, p. 88, grifos da autora).

Eis a questão crucial: qual o lugar do gênero e da diversidade sexual na escola? Toda pergunta pressupõe uma resposta, ei-la: "a escola é atravessada pelos gêneros; é impossível pensar sobre a instituição sem que se lance mão das reflexões sobre as construções sociais e culturais de masculino e feminino" (LOURO, 2008a, p. 89, grifos da autora). Neste sentido, pensar a escola como espaço institucional e de sociabilidades sem considerar a complexidade das questões de gênero e de sexualidades é alijar nossas alunas e alunos de uma formação ampla que lhes possibilite um novo olhar em relação ao outro e às suas diferenças, que são constitutivas de sua identidade. Cansados de discursos oficiais, que na prática deixam lacunas imensas, de que a "escola pública de gestão compartilhada" seria o ideal, deveríamos colocar em prática uma efetiva implementação de políticas públicas que viabilizem, de fato, uma abordagem planejada, sistematizada, e organizada sobre gênero, sexualidades e identidades no cotidiano da sala de aula e na formação inicial e continuada de professores.

\section{Referências}

ALTMANN, H. Orientação sexual nos parâmetros curriculares nacionais. In: Estudos Feministas, Florianópolis, v. 9 n. 2, p. 575-595, 2001.

BORGES, Zulmira N.; MEYER, Dagmar E. Limites e possibilidades de uma ação educativa na redução da vulnerabilidade à violência e à homofobia. In: Ensaio: avaliação e políticas públicas em educação. 2008, janeiro/março, 16(58), 59-76.

BRASIL. Parâmetros Curriculares Nacionais: temas transversais para $\circ$ Ensino Fundamental. Brasília/Secretaria de Educação Fundamental: MEC/SEF, 1997.

Plano Nacional de Educação em Direitos Humanos. Brasília: Secretaria Especial dos Direitos Humanos/Ministério da Educação/Ministério da Justiça/ UNESCO, 2008. 
CAMARGO, Flávio Pereira. Revendo as margens: a (auto)representação de personagens homossexuais em contos de Caio Fernando Abreu. Tese (Doutorado em Literatura) - Universidade de Brasília, Instituto de Letras - Programa de Pós-Graduação em Literatura, 2010.

CONFERÊNCIA NACIONAL DE EDUCAÇÃO (CONAE). Construindo o sistema nacional articulado de Educação: o plano nacional de educação, diretrizes e estratégias: documento final. Brasília: MEC, 2010. 164p. Disponível em: <http://conae.mec.gov.br/images/stories/pdf/pdf/documetos/documento_final.pdf>

D'AMBRÓSIO, Ubiratan. Educação para uma sociedade em transição. Campinas: Papirus, 1999.

ERIBON, Didier. Reflexões sobre a questão gay. Rio de Janeiro: Companhia de Freud, 2008.

FACCO, Lúcia. Era uma vez um casal diferente: a temática homossexual na educação literária infanto-juvenil. São Paulo: Summus, 2009.

JUNQUEIRA, Rogério Diniz. Homofobia: limites e possibilidades de um conceito em meio a disputas. In: Bagoas. Revista de Estudos gays. Universidade Federal do Rio Grande do Norte, Centro de Ciências Humanas, Letras e Artes. Natal: EDUFRN, 2007, vol. 01, n. 01, jul./dez. 2007, p. 01-22.

LOURO, Guacira Lopes. Gênero, sexualidade e educação: uma perspectiva pós-estruturalista. Petrópolis: Vozes, 2008a.

. Um corpo estranho: ensaios sobre sexualidade e teoria queer. Belo Horizonte: Autêntica, 2008b.

RIOS, Roger Raupp. Homofobia na perspectiva dos Direitos Humanos e nos contexto dos Estudos sobre preconceito e discriminação. In: JUNQUEIRA, Rogério Diniz (Org.). Diversidade sexual na educação: problematizações sobre a homofobia nas escolas. Brasília: MEC/Secretaria de Educação Continuada, Alfabetização e Diversidade, UNESCO, 2009.

SANTOMÉ, Jurgo Torres. As culturas negadas e silenciadas no currículo. In: SILVA, Tomaz Tadeu da (Org.). Alienígenas na sala de aula. Petrópolis: Vozes, 1995.

SEFFNER, Fernando. Equívocos e armadilhas na articulação entre diversidade sexual e políticas de inclusão Escolar. In: JUNQUEIRA, Rogério Diniz (Org.). Diversidade sexual na Educação: problematizações sobre a homofobia nas escolas. Brasília: MEC, Secretaria de Educação Continuada, Alfabetização e Diversidade, UNESCO, 2009.

SILVA, Tomaz Tadeu da. Teorias do Currículo: uma introdução crítica. Porto: Porto Editora Ltda, 2000.

. Currículo e identidade social: territórios contestados. In: (Org.). Alienígenas na sala de aula. Petrópolis: Vozes, 2011.

VIANA, Fabricio. O armário: vida e pensamento do desejo proibido. $3^{a}$ ed. Rev. e ampl., Blumenau, SC: Ed. do Autor, 2010. 


\title{
PROFESSORES HOMOSSEXUAIS - SUAS VIVÊNCIAS FRENTE À COMUNIDADE ESCOLAR.
}

\author{
HOMOSEXUAL TEACHERS - THEIR EXPERIENCES IN FRONT OF THE \\ SCHOOL COMMUNITY
}

Luana Pagano Peres Molina'

\begin{abstract}
Resumo:
Este trabalho tem como objetivo apresentar uma discussão referente à problemática da vivência diária do professor/professora homossexual frente à instituição escolar, cujo pressuposto inicial parte da premissa que estes professores sofreram e vem sofrendo, algum tipo de preconceito devido sua orientação sexual. No desenvolvimento, partimos para uma abordagem qualitativa e fundamentando-se na analise de discurso, ou seja, conhecendo as experiências de professores e professoras por meio de suas narrativas. Nosso resultado é composto por relatos onde pudemos identificar a escola como um ambiente que reflete o sexismo que perpassa toda a sociedade, reproduzindo com frequência, as estruturas sociais, reforçando os preconceitos e privilégios de um sexo sobre o outro.
\end{abstract}

Palavras Chaves: Professoras e Professores; Homofobia; Homossexualidade.

\begin{abstract}
:
This paper have to porpose develop a discussion about the daily problems experienced by homosexual teachers - whether men or women - into the school. Our initial assumption assumes that these teachers had suffering and still have suffering some kind of prejudice because of their sexual orientation. During the discussion, we adopt a qualitative approach and we base our analysis on the basis of discourse, in other word, we try to learn the experiences of teachers through their life narratives. The end result of this work consists of reports where we could identify the school as an environment that reflects the sexism that pervades all the society, often reproducing the social structures, and thus reinforcing the prejudices and privileges of one sex over the other.
\end{abstract}

Keywords: Homosexuality, Homophobia, Teachers.

\section{Introdução}

O outro é tudo aquilo (humano, não - humano, visível, não - visível) que me arranca da pretensa estabilidade de uma identidade fixa (um modo padronizado de pensar, sentir, agir), provocando-me com um incessante convite para diferentes formas de ser - estar no mundo

Nilson Dinis ${ }^{10}$

9 Mestranda em História Social, especialista em Psicologia Aplicada à Educação e graduada em História. Universidade Estadual de Londrina. e-mail: Ippmolina@hotmail.com

10 DINIS, Nilson Fernandes. Educação, relações de gênero e diversidade sexual. In: Educ. Soc. Campinas: Vol. 29, n. 103, pp. 477-492, maio/ago. 2008. Disponível em «<www.cedes.unicamp. br $\gg$. 
Amar alguém do mesmo sexo, entregar-se à dor e à delícia de sentirse apaixonado como em qualquer relacionamento no qual criamos laços de ternura, torna-se mais difícil para os homossexuais, uma vez que os riscos do encontro e desencontro de amar alguém simbolizam romper com o mundo sociocultural que os indivíduos estão inseridos. Um mundo que esconde as diversas faces do amor e prega um discurso heterossexista, levando a maioria dos homossexuais a uma árdua luta por sua identidade, autonomia e direitos. Direitos como seres humanos. Direito ao amor.

Ser homossexual, reconhecer-se homossexual, traz à tona a revolução dos tempos, sentimentos e sonhos de milhares de pessoas. Portanto, retrataremos uma pequena parcela dessa luta, que incansável, dedica-se a grande revolução do amor.

Ao trabalhar a homossexualidade inserida na nossa tradição ocidental judaico-cristã, lidamos com uma temática que foi, e ainda é de alguma maneira, vista e tratada como um pecado abominável, um crime, uma imoralidade. Segundo o antropólogo Luiz Mott, a importância de estudar sobre a homossexualidade na realidade brasileira é ter a possibilidade de desvendar as raízes do preconceito em nossa sociedade, contribuindo para erradicar a intolerância e a crueldade contra os homossexuais.

Dentro da diversidade sexual, os grupos de gays, lésbicas, travestis e transexuais são vítimas de preconceitos e discriminações, devido a sua orientação sexual e à identidade de gênero. A homofobia, preconceito contra pessoas que se relacionam afetivo-sexualmente com outras do mesmo sexo, é diariamente marcada por gestos, olhares, palavras, discursos, agressões e até mesmo assassinatos, que Luiz Mott, em seu livro "Homossexualidade: Mitos e Verdades" retrata como um ódio doentio contra aqueles que ousam transgredir a ditadura heterossexista:

A este ódio mórbido contra a homossexualidade a Psicologia chama de homofobia internalizada, provocando nestes doentes, sintomas diversos, incluindo neurose de frustração sexual, suicídio e atos de violência, como agressões e assassinato sádico de homossexuais (MOTT, Luiz. 2003:23)

A homossexualidade foi ao longo dos tempos e das diferentes culturas, motivo de punição, de vergonha, segregação e violência contra todos aqueles que atravessassem a fronteira da heteronormatividade". Desta maneira, encontramos neste artigo, pontuações e contextualizações sobre a desconstrução do ser homosexual e pluralizando os discursos da identidade de gênero, para que possamos compreender a urgência das políticas identitárias e a ascensão do movimento homossexual.

11 Entendemosporheteronormatividade a obsessão com a sexualidade normatizante heterossexual, através de discursos que descrevem a situação homossexual como desviante e imoral. Colocando desta maneira, segundo Débora Britzman, uma imagem de identidade sexual heterossexual como "normal" e "natural". 
Rosa Maria R. Oliveira pontua a necessidade de trabalharmos o conceito de gênero de forma mais livre e menos rigorosa e, não como um lugar privilegiado nos conflitos sociais de maneira a assegurar uma reprodução social dentro da dicotomia homens/mulheres. As análises sociológicas das relações de Gênero, sustentadas pelos conceitos de papéis sexuais, desafiaram essa visão essencialista da biologia sobre as identidades humanas à medida que proporcionaram o questionamento referente à construção histórico-cultural das pessoas e à importância do meio sociocultural em sua formação. Assim:

O estudo de gênero e sua compreensão surgem pela forma como a cultura expressa as diferenças entre homens e mulheres e de que modo a caracterização das diferenças inerentes ou aprendidas entre os sexos pode servir como ponto auxiliar para compreensão da exclusão das pessoas que vivem a experiência homoerótica como entes capazes de direitos e obrigações. (OLIVEIRA, 2009: 16).

Os sujeitos aprendem o conceito de status sexual, segundo essa autora, através dos comportamentos apropriados a esse status, ou seja, é dentro desta linha que se conceberá a masculinidade e a feminilidade, que se convertem em identidades psicológicas a cada pessoa. Portanto, a participação diversa dos homens e mulheres nas instituições sociais, econômicas, políticas e religiosas são marcadas pela identificação dos diferentes papéis sexuais, incluindo atitudes, valores e expectativas que uma dada sociedade conceitualiza como femininas ou masculinas.

Assim, ao dizer que as relações de gênero são construídas socialmente, isso implica dizer que, elas se dão de forma diferente de uma sociedade para outra e em épocas diferentes; ou seja, os sujeitos históricos têm suas relações fundamentadas por um padrão dominante no gênero como: homem/ mulher, provedor/ reprodutor, público/ privado, dominação/ submissão.

Ao estudarmos sobre a homossexualidade e, consequentemente, a desconstrução dos papéis sexuais do feminino e masculino, devemos repensar a representação e os discursos de identidade, do conhecimento e do poder cultural que circulam no aparato do saber/poder na sociedade, para que possamos (re)analisar e (re)construir o discurso da própria sexualidade.

A autora Débora Britzman afirma que pensar a identidade significa não apenas ver esses elementos como efeitos constitutivos das relações sociais e da história, mas também como capazes de rearticular o desejo e o prazer. Quando se trata de questões de desejo, de amor e de afetividade, a identidade é capaz de surpreender a si mesma; de criar formas de sociabilidade, de política e de identificação que desvinculem o eu dos discursos dominantes da biologia, da natureza e da normalidade.

Nenhuma identidade sexual - mesmo a mais normativa - é automática, autêntica, facilmente assumida; Nenhuma identidade sexual existe sem negociação ou cons- 
trução. Não existe, de um lado, uma identidade heterossexual lá fora, pronta, acabada, esperando para ser assumida e, de outro lado, uma identidade homossexual instável, que deve se virar sozinha. Em vez disso, toda identidade sexual é um construto instável, mutável e volátil, uma relação social contraditória e não finalizada. (BRITZMAN, 1996:74)

Ainda segundo essa teórica, os mitos criados acerca da homossexualidade, ao longo dos tempos, acabam por eficazmente produzir noções normativas que posicionam a heterossexualidade como sendo a sexualidade estável e natural, inviabilizando o sujeito homossexual de vivenciar com plenitude seus direitos como cidadãos, levando-os a um isolamento social e emocional. Assim entendemos que:

A identidade heterossexual normativa exija que se construa, ao mesmo tempo, a homossexualidade como falta o que se deixa de pensar é que todas as sexualidades devem ser construídas, que nossas práticas e interesses são socialmente negociados durante toda nossa vida e que a moldagem sexual não precisa estar presa a estruturas de dominação e sujeição. (BRITZMAN, 1996:91)

Neil Franco explica que a homossexualidade passou a referir-se a uma pessoa distinta, tornando-se o oposto em relação à heterossexualidade após a consolidação das sociedades industrializadas ocidentais, o que não acontecia antes do século XIX. Desta forma, na segunda metade do século XX, os processos de industrialização, urbanização e desenvolvimento socioeconômico foram representativos na estruturação de identidades gays e lésbicas em diversas sociedades ocidentais, inclusive na brasileira.

Portanto, acreditamos que, em vez de ver a questão da homossexualidade como sendo de interesse apenas para aquelas pessoas que são homossexuais, devemos considerar a forma como são construídos os discursos identitários dominantes da heterossexualidade que produzem seu próprio conjunto de ignorâncias, tanto sobre a homossexualidade quanto sobre a heterossexualidade, alimentando a homofobia e inviabilizando as possibilidades de sentimentos e experiências do sujeito no seu universo sexual.

\section{A Escola como Lugar das Diferenças e da Homofobia}

Acreditamos que a escola delimita espaços, apontando aqueles(as) a serem modelos; permitindo também que os sujeitos se reconheçam, ou não, nesses moldes e, caso não haja esse reconhecimento, ela se torna mais do que discriminatória; mas também, insuficiente (no sentindo de abrangência das diferenças), incompetente e ineficaz.

As discriminações por gênero, etnia e orientação sexual são reproduzidas em todos os espaços da sociedade brasileira, incluindo o espaço da escola. O Brasil tem se esforçado para conseguir erradicar essas desigual- 
dades; tem sido signatário de documentos em prol da igualdade de direitos e tem criado diversos projetos, programas e leis que incluem a equidade de gênero como condição fundamental para o respeito às diferenças. Mas não bastarão leis e projetos, se não houver transformações mais estruturantes nas práticas cotidianas de homens e mulheres. No caso de considerarmos a escola como um espaço privilegiado de transformação social, deveremos incentivar ações que estimulem reflexões individuais e coletivas, a começar com a discriminação contra seu próprio corpo docente que tem como orientação sexual a homossexualidade.

O ambiente escolar deve ser caracterizado por subsidiar a construção da autonomia e criticidade, não somente de seus alunos, mas principalmente de todas as pessoas que compõem seu cenário para que, desta maneira, também possamos alcançar a reflexão que leve a uma promoção da equidade de gênero no espaço escolar.

Entendemos a escola como um lugar que deve privilegiar a formação cidadã e a transformação social, segundo Lionço e Diniz é necessário percebermos que ao construir e transmitir conhecimento, também fabricamos sujeitos e subjetividades:

Reproduz padrões sociais, iníquios, perpetua concepções e valores hegemônicos, naturaliza relações autoritárias, reitera hierarquias opressivas, sanciona clivagens sociais e legitima a acumulação desigual de recursos e prestígio. (DINIZ. 2009:162)

Devemos tomar consciência que a educação é um produto cultural, uma vez que foi construída histórica e culturalmente, como um processo disciplinador, normalizador e reprodutor de desigualdades. Dagmar Meyer, em "Gênero e educação: teoria e política", pontua o espaço escolar e suas práticas pedagógicas a partir de uma identidade que é norma, aceita e legitimada, sendo heterossexual, de classe média e judaico-cristã. Assim, o âmbito escolar como espaço da diferença é reduzido às instâncias sociais, envolvidas pelo efeito dessa produção; Portanto será a diferença que marcará e reduzirá o indivíduo ou grupo de indivíduos a ela.

Devemos perceber o espaço escolar em toda sua dimensão como um campo político, desde seu currículo, disciplinas, normas regimentais, suas formas de avaliação, tipos de materiais didáticos; que acabam por refletir e produzir as desigualdades de gênero, de raça e etc., incentivando o preconceito e a discriminação. Por isso, atualmente, através de algumas políticas públicas (como o caso do Programa Brasil sem Homofobia), o espaço escolar brasileiro vem sendo repensado de maneira a contribuir de forma mais eficaz no enfrentamento do que impede ou dificulta a participação social e política e que, ao mesmo tempo, contribui para a reprodução de lógicas perversas de opressão e incremento das desigualdades.

Os valores e os modelos de conduta produzidos na escola e transmitidos por ela, tanto por meio dos conteúdos da educação formal, como através da interação cotidiana com colegas, educadoras e educadores, 
encarnam todos os preconceitos e as desigualdades que são comuns na sociedade, legitimando-os pelo peso da instituição educativa e pela sanção coletiva da comunidade escolar. Guacira Lopes Louro observa que, embora não se possa atribuir à escola o poder e a responsabilidade de explicar identidades sociais ou de determiná-las de forma definitiva, é necessário reconhecer que "suas proposições, suas imposições e proibições fazem sentido, têm 'efeitos de verdade', constituem parte significativa das histórias pessoais. (LOURO, 2009:21.)

Guacira Lopes Louro aponta em seus livros, a ideia da escola como um espaço de construções das diferenças, ou seja:

Diferença, distinções, desigualdades... A escola entende disso. Na verdade, a escola produz isso. Desde seus inícios, a instituição escolar exerceu uma ação distintiva. Ela se incumbiu de separar os sujeitos - tornando aqueles que nela entravam distintos dos outros, os que a ela não tinham acesso. Ela dividiu também, internamente, os que lá estavam, através de múltiplos mecanismos de classificação, ordenamento, hierarquização. A escola que nos foi legada pela sociedade ocidental moderna começou por separar adultos de crianças, católicos de protestantes. Ela também se fez diferente para os ricos e para os pobres e ela imediatamente separou os meninos das meninas. Concebida inicialmente para acolher alguns - mas não todos - ela foi, lentamente, sendo requisitada por aqueles aos quais havia sido negada. Os novos grupos foram trazendo transformações à instituição. Ela precisou ser diversa: organização, currículos, prédios, docentes, regulamentos, avaliações iriam, explícita ou implicitamente, "garantir" - e também produzir - as diferenças entre os sujeitos. (LOURO,1999: 57)

Dessa forma, acreditando que a escola seja um reflexo ativo da sociedade, de que maneira esse ambiente lida com professores cuja orientação sexual é a homossexualidade?

A escola acaba por inviabilizar a possibilidade de trabalharmos questões referentes à sexualidade, discriminando esses professores e refletindo 0 sexismo que perpassa toda a sociedade, reproduzindo com frequência as estruturas sociais, reforçando os preconceitos e privilégios de um sexo sobre o outro.

Portanto, a escola atua tanto na instrução como ainda na interiorização de hábitos e valores que possam dar suporte à sociedade em construção, preparando as crianças e jovens, moral e fisicamente, tendo por base a educação do corpo; ou seja, capazes de expressar e exibir os signos, crenças, normas e as marcas corporais da sociedade. Mais do que isso, a escola tende a reproduzir as assimetrias sociais entre os gêneros reforçando privilégios e preconceitos de uns sobre outros.

O campo escolar deve ser visto como um espaço social, onde, em meio ao seu cotidiano, é um gerador de conflitos, tensões e disputas em torno de concepções de escola, currículo, docência, livro didático, socieda- 
de, Estado, público/privado, família, direitos e etc. As autoras Lionço e Diniz, completam:

Essas tensões se atrelam a dinâmicas de produção e atualização de hierarquias e processos de (des)legitimação, (des)qualificação, inclusão e exclusão de sujeitos, saberes, modos de ver, práticas e agendas políticas e educacionais. (LIONÇO, DINIZ. 2009:163)

Desta maneira, as discussões de temáticas referentes à diversidade sexual e aos direitos sexuais nas escolas necessitam de suporte de políticas públicas na área da educação e de mobilizações sociais que objetivem desestabilizar a produção de hierarquias, opressões e padrões heteronormativos, que histórica e culturalmente moldam as relações de gênero.

Se a sociedade é constituída por uma diversidade de culturas, crenças, etnias, estilos de vida entre outras variadas características; a escola, por ser a representação desta sociedade, tende a reproduzir todas as relações sociais, inclusive as práticas de discriminação (mais especificamente a homofobia) em suas salas de aulas, pátios, corredores, banheiros, enfim, em todos os espaços por onde circulam estudantes, funcionários em geral e professores. (FACCO, 2009: 18).

Neste trabalho retratamos uma das grandes marcas de desigualdade que se encontra inserida no cotidiano de milhares de sujeitos: a homofobia. Este é um termo criado para designar especificamente a aversão, o ódio ou a discriminação contra pessoas homossexuais. Entendemos o preconceito e sua fundamentalização discriminatória como um:

tratamento desfavorável dado habitualmente a certas
categorias de pessoas e/ou grupos. Refere-se a proces-
sos de controle social que servem para manter a distân-
cia social entre determinados grupos, através de um
conjunto de práticas, mais ou menos institucionalizadas,
que favorecem a atribuição arbitrária de traços de infe-
rioridade. (CANDAU, 2003: 18)

Ressaltamos que a homofobia é um problema social e político muito grave e que deve ser estudada dentro de uma variante que irá se modificar de intensidade e freqüência, de acordo com cada sociedade e no interior de sua cultura.

Junqueira coloca em seu artigo que o termo homofobia é um neologismo resultante da justaposição de dois radicais gregos - óuós (semelhante) e póßos (temor, medo). O conceito logo teve sua abrangência semântica ampliada e passou a englobar uma variada gama de sentimentos e atitudes negativas em relação aos homossexuais e à homossexualidade.

Com efeito, nesse sentido, o termo costuma ser insistentemente empregado em referência a conjuntos de emoções negativas (tais como aversão, desprezo, ódio, desconfiança, desconforto ou medo) em relação a pessoas 
homossexuais ou assim identificadas. Essas emoções, em alguns casos, seriam a tradução do receio (inconsciente e "doentio") de a própria pessoa homofóbica ser homossexual (ou de que os outros pensem que ela seja). Assim, seriam indícios (ou "sintomas") de homofobia o ato de se evitarem homossexuais e situações associáveis ao universo homossexual, bem como a repulsa às relações afetivas e sexuais entre pessoas do mesmo sexo.

(JUNQUEIRA, 2009:370).

Ainda segundo esse autor, a íntima relação entre homofobia e normas de gênero tanto se traduz em noções, crenças, valores, expectativas; quanto em atitudes, edificação de hierarquias opressivas e mecanismos reguladores discriminatórios bastante amplos. Assim, pode comportar drásticas consequências a qualquer pessoa que ouse descumprir os preceitos socialmente impostos em relação ao que significa ser homem e ser mulher:

A homofobia, nesse sentido, transcende tanto aspectos de ordem psicológica, quanto a hostilidade e a violência contra pessoas homossexuais, bissexuais, travestis, transexuais e intersexos etc. Ela, inclusive, diz respeito a valores, mecanismos de exclusão, disposições e estruturas hierarquizantes, relações de poder, sistemas de crenças e de representação, padrões relacionais e identitários, todos voltados a naturalizar, impor, sancionar e legitimar uma única seqüência sexo-gênero-sexualidade, centrada na heterossexualidade e rigorosamente regulada pelas normas de gênero. (JUNQUEIRA, 2009:375)

A negação ao "outro", segundo Lúcia Facco (2009), faz parte do processo discriminatório, onde as leituras das diversas identidades alheias, baseadas em preconceitos e estereótipos, sustentam e perpetuam as práticas discriminatórias.

Mesmo atualmente presenciando um período de possível reconhecimento da homossexualidade como mais uma manifestação da diversidade sexual, como são os casos das lésbicas, gays, bissexuais, travestis e transexuais, percebemos este reconhecimento ser anulado cotidianamente em virtude das consequências da homofobia. Esta violência se manifesta de diversas maneiras, e a sua forma mais grave resulta em ações de agressões verbais e físicas, podendo levar até ao homicídio:

Sabemos, portanto, que gays, lésbicas e transgêneros não apenas tem menos direitos do que os indivíduos heterossexuais, mas que também estão mais sujeitos à violência, à discriminação e ao preconceito em diversos âmbitos da vida social, tanto na vida adulta quanto na infância e na juventude. (MELLO; GROSSI; UZIEL; 2009:161).

A homofobia tem sua origem causada pelas motivações que fundamentam o racismo e qualquer outro preconceito. Nomeadamente, uma 
oposição instintiva a tudo o que não corresponde à maioria com que o indivíduo se identifica e às normas implícitas e estabelecidas por essa mesma maioria.

Desta maneira, o preconceito construir-se-á dentro desta conceituação: uma via de mão dupla que servirá para resistir a uma ameaça ao diferente e também para mantê-lo à distância - vale ressaltar que a reprodução do preconceito enaltece uma postura de desconfiança, hostilidade, entre outras possibilidades de agressões.

Longe de se constituir apenas uma questão semântica, essa proposta educacional objetiva a discussão em escala mais ampla: dos currículos escolares (adaptados ou não), das práticas educacionais que possam abarcar as minorias sociais, trabalhando primariamente as questões das diferenças físicas, culturais, sociais. Neste caso, os deficientes, imigrantes, os negros, populações indígenas, homossexuais, transgêneros, ou seja, uma imensa massa humana representada pela sua não inclusão no âmbito da escola.

\section{As vozes de professores e professoras homossexuais nas escolas}

Enquanto a informação só tem valor enquanto é nova, a verdadeira narrativa não se entrega à imediatez do tempo para explicar os fatos, pelo contrário, depois de muito tempo é capaz de suscitar espanto e reflexão.

Walter Benjamin - O narrador.

Como professores e professoras homossexuais vivenciam e se defrontam com questões referentes à homofobia, quando esta, de maneira sutil e por vezes, com certa invisibilidade, perpassa nossa cultura coletiva e instâncias sociais, como o caso do espaço escolar? De que maneira, as permanências e rupturas dessa homofobia, construída dentro de nosso contexto cultural, se confrontam, permanecem, tensionam e refletem a interpretação da realidade e de vivência destes professores?

Partimos para uma abordagem qualitativa, a qual possibilita à pesquisadora estabelecer à interação com o sujeito pesquisado e com o contexto sociocultural em que está inserido. A partir disso, nossa intenção fundamenta-se na análise do discurso, conhecendo as experiências de professores e professoras por meio de suas narrativas e, intencionalmente, desta maneira, realizamos um encontro na história de vida de cada sujeito para retirarmos fragmentos que possam ter sido significativos para eles e elas em determinados momentos de suas vivências, por meio do foco do nosso trabalho, no caso, a homofobia no espaço escolar.

Nossa intenção foi descobrir como estas experiências foram se constituindo, pois pensamos na história como um tempo narrado, um tempo constituído de fragmentos e singularidades, ou seja, o que nos interessa são as experiências no sentido proposto por Larrosa: "A experiência é o que nos 
passa, o que nos acontece, o que nos toca" (LARROSA, 2002, 21)

Michel Connelly e Jean Clandini defendem as investigações narrativas no campo das abordagens qualitativas, já que estas investigações se baseiam na experiência vivida e na qualidade de vida e de educação dos sujeitos da pesquisa, como vemos:

A narrativa e a vida vão juntas e, portanto, o atrativo principal da narrativa como método é sua capacidade de reproduzir as experiências da vida, tanto pessoais como sociais, de formas relevantes e cheias de sentindo. (CONNELLY;CLANDINI;2009:195)

Para estes teóricos, o uso das narrativas como fonte documental traz consigo a possibilidade de nos aproximarmos ou compreendermos como estas pessoas que narram suas histórias vivem suas vidas de maneira individual e socialmente. Desta forma, os estudos da narrativa são o estudo da forma como os seres humanos experienciam o mundo onde estão inseridos.

Para Larossa (2002), as narrativas são uma modalidade discursiva, na qual as histórias que contamos e as histórias que ouvimos, produzidas e mediadas no interior de determinadas práticas sociais, passam a construir a nossa história, a dar sentido a quem somos e a quem são os outros, constituindo assim as identidades de gênero, sexual, racial, religiosa, profissional, de classe social, entre outras.

Ao optar por esse tipo de investigação, é preciso considerar que as narrativas são construídas e reconstruídas em relação a textos - da família, da igreja, da escola, da mídia, entre outros. A narrativa é produzida a partir das vivências e suas relações sociais, ou seja, elas acontecem em um determinado momento histórico-social.

Segundo o teórico Paul Thompson, em seu livro "A voz do Passado" (1992), a História Oral favorece o aparecimento de um novo tipo de fonte, o relato oral, que diferente da autobiografia, é produzido pela interação entre entrevistador e entrevistado, visando à obtenção de informações sobre uma realidade em uma determinada comunidade, sociedade.

Thompson acredita que uma das mais profundas lições da história oral é a singularidade, tanto quanto a representatividade, de cada história de vida. Desta forma, torna-se possível compreendermos melhor o papel do sujeito, que passa a combinar sua memória pessoal com a memória coletiva, criando uma espécie de imagem coletiva, refletindo assim, questões sociais.

A evidência oral, transformando os "objetos" de estudo em "sujeitos", contribui para uma história que não só é mais rica, mais viva e mais comovente, mas também mais verdadeira.

(THOMPSON, 1992,137)

Neste trabalho foram realizadas entrevistas com dois professores gays e uma professora lésbica, todos com ensino superior completo, que atuam ou atuaram no Ensino Fundamental I e II e/ou Ensino Médio. A professora possui 36 anos, atua há 12 anos na rede estadual do Paraná, na disciplina de 
matemática. Já um dos professores, possui 44 anos e atuou na Rede Privada de Ensino e em cursinhos pré-vestibulares, ao longo de 9 anos, ministrando a disciplina de História. O outro professor tem 39 anos e atuou no Ensino Médio e em cursinhos pré-vestibulares durante 10 anos na área de Literatura.

A princípio, a ideia era que trabalhássemos com cerca de 3 professores gays e 3 professoras lésbicas, somando 6 entrevistados ao todo. Mas, ao longo do desdobramento do trabalho foram encontradas muitas dificuldades em localizar professores que sentiam-se a vontade em participar do projeto, falando sobre suas experiências pessoais, focando principalmente em situações de homofobia. Mesmo diante deste problema, alguns outros professores desistiram na última hora pelo conflito de falta de horário a disponibilizar para a realização das entrevistas. Devido a estes casos, trabalhamos com 3 pessoas que foram suficientes para abranger o conteúdo em sua toda intensidade e urgência nos relatos aqui coletados sobre o preconceito contra os homossexuais no âmbito escolar.

Para a pesquisa aplicamos um questionário prévio para identificação de um perfil deste professor(a) e logo em seguida realizávamos a entrevista que era gravada e depois transcrita.

O questionário aplicado era composto de dez questões de identificação pessoal, no intuito de traçarmos um perfil dos entrevistados, como por exemplo, se eles se reconhecem como homossexual, quando isso aconteceu, se eles se aceitam e se assumem publicamente, inclusive no seu ambiente de trabalho e no âmbito familiar. Também foi informado, neste questionário, seu nível de escolaridade, seu tempo de atuação como professor e em qual disciplina ele ministra aulas. Desta forma, buscou-se uma melhor compreensão da vivência desses professores.

A partir disso, seguimos para as entrevistas semiestruturadas, por meio de perguntas que focaram mais especificamente a percepção dos professores sobre a homofobia na escola, como por exemplo, se lidam e como eles lidam com a homofobia e de que maneira isso interferiv e interfere na convivência diária com os outros componentes da organização escolar, além de como entendem e veem a importância de serem trabalhadas questões sobre a sexualidade e o combate à homofobia na escola.

A prática discriminatória perpassa este ambiente, refletindo os processos discriminatórios internalizados na sociedade, construídas pelo olhar social, que é um olhar dominante, mirando para a negação do outro. Por isso, nossos relatos neste momento, refletem a vivencia desses professores frente à homofobia na escola:

E na rede particular eu era professora em uma escola de irmãs [...], assim que eu resolvi vivenciar isso, eu contei a elas e fui mandada embora. Mas antes dessa despedida da escola, eu fiquei ainda numa sala por dois meses, porque eles ainda não sabiam como iriam fazer esta dispensa, sem que gerasse um conflito por parte trabalhista. Enquanto isso, eles me deram trabalhos manuais para fazer em uma salinha, e que eu não pudesse ter contato com os alunos e nem com os colegas de trabalho. (Profa. Cristina) 
A Professora ainda afirma que:

Por parte dos alunos eu não sentia discriminação, mas por parte dos colegas e da escola foi muito visível.

Ao perguntar sobre seus sentimentos e postura nesta situação especifi$c a$, vivenciada na escola que exercia a docência, ela respondeu:

foram dois meses muito difíceis, porque eu ainda estava me descobrindo, começando esse relacionamento, ela também era casada, a gente tinha saído de casa para morar juntas e vivenciando tudo is[...] so, essa falta de emprego e esse desespero de não saber o que íamos fazer da vida [...] Eu cheguei a entrar com um processo em Cornélio, como todo mundo sabia, os juízes, advogados, promotores, não havia como o colégio alegar que não foi por isso, porque neste colégio eu dava aulas para pessoas de classe média alta da cidade; Então quando minha sentença saiu, foi uma sentença lindíssima, muito bem colocada, pontuada, a juíza foi iluminada, então assim, colocou tudo de maneira belíssima. E eu ganhei em primeira instância e quando eles recorreram e foi para Curitiba, o desembargador de lá colocou como falta de provas [...]

O Professor Celso, ao responder sobre se vivenciou algum tipo de homofobia na escola, respondeu:

não me lembro de nenhum preconceito comigo. Eu nunca percebi nenhuma violência, discriminação pelo fato de eu ter sido bissexual ou ser homossexual.

Porém, ao ser questionado se conhecia algum outro professor ou professora homossexual que haviam sofrido com a homofobia, ele relatou: Sim, sim. Eu tive colegas que trabalharam comigo [...], ele era negro, bailarino e gay. Eu acho que a questão com ele era mais complicada, porque ele era um gay bastante afetado, extremamente criativo, mobilizava a escola de uma maneira muito interessante. Por ser negro, então, as pessoas o julgavam pela cor da sua pele, pela sua sexualidade e ele era muito desvalorizado.

O professor Caio, de Literatura, ao ser questionado sobre algum tipo de discriminação devido a sua orientação sexual diz:

Com a direção, eu sempre dou muita sorte, morando, no estado de São Paulo nessa história de cursinho eu viajava com um professor de História, que se tornou muito meu amigo e era casado com uma moça que fez faculdade comigo, que tinha feito Letras, aí viajávamos os dois por várias cidades do interior dando aulas e uma delas era aqui em Londrina, num colégio daqui, que fomos contratados. E o que aconteceu foi: A droga da escola chamou esse professor para perguntar sobre mim (esse professor de História), se ele sabia, se eu tinha tido alguma história com aluno, como era o meu comportamento e ele falou:

- "Você esta perguntando isso por quê?"

- "Não. É porque a gente quer contratar, ele é um professor muito bom.", e ele:

- "Você vai perguntar pra ele se ele tem esse tipo de problema? Isso você faz 
com todos os professores? Porque se você estiver tendo só com ele, eu não vou nem contar pra ele que isso tá acontecendo, só vou falar que não deu certo e a gente não vai trabalhar."

- "Não, não é isso, pelo amor de Deus..."

- "Não, porque a competência profissional, não sei se é assim que você mede, mas você me ofende vindo perguntar pra mim sobre a vida dele. Você me ofende como professor, como educador, se eu cheguei aqui com ele. Você não perguntou pra mim se eu sou gay porque, ele você

E conclui sua narrativa sobre este fato específico:

Eu realmente tive bons amigos, porque quantos fariam isso? Porque esse cara tem um diferencial, ele era educador, era um professor de História que não deixaria passar isso. Eu não sei se há muitos assim, profissionais da educação que têm essa visão que eu acho que é necessário

Diante destes relatos, entendemos a escola como um lugar que fala, se posiciona, de acordo com seu perfil pedagógico, seus funcionários, se é de caráter religioso ou não, a classe social que engloba a população discente e docente, ou seja, há vários tipos de escolas, sejam particulares, como públicas de periferias ou de zonas centrais, religiosas, laicas e por assim adiante, possuindo populações heterogêneas do ponto de vista das multiplicidades sociais que as habitam.

E são estas diferenciações que trarão luz a uma homofobia mais sutil ou mais brutal. Desta maneira, os dois relatos que temos, são dois relatos de professores que obtiveram diferentes vivencias pessoais no âmbito profissional, de acordo ao que referem-se a sua homossexualidade. Enquanto um não sofreu diretamente com algum tipo de discriminação, nossa outra professora foi mandada embora e proibida de ter contato com seus alunos. Já esta mesma professora ao reassumir suas aulas no ensino público, apesar do trauma causado pela escola religiosa que a havia mandado embora, relatou a seguinte experiência:

o corpo docente, eles achavam que eu fosse sofrer muito a repressão dos alunos, porque aluno adolescente tem seu lado malvado, eles são terríveis mesmo. E minhas salas eram salas de quarenta alunos. E voltei para sala com muito medo, porque sempre fui uma professora severa, não era uma pessoa que deixava indisciplina na sala e queria continuar com a mesma postura. E devido a isso, quando eu começa a ter esse enfrentamento com eles, na minha cabeça o meu inconsciente já vinha apitando, "Agora eles vão te xingar", e vinha todo tipo de palavrão na minha mente, mesmo assim, eu continuava tendo a mesma postura. E nenhum momento eles tiveram esse tipo de processo comigo, nunca revidaram, brigaram, até porque eu nunca perdi a minha postura com educação com eles, eu brigava e tudo, mas nunca os desrespeitei. E quando eu saia e batia o sinal do intervalo, eu ia atravessar o pátio para chegar à sala dos professores, via um monte de gente, aquele monte de adolescentes, me vinha na cabeça, agora eles vão gritar, agora eles vão me xingar...eu tinha medo daquilo... 
As narrativas deixam transparecer o permanente estado de vigilância exercido ao longo de todo o processo formativo. Para Louro, a homofobia é consentida e ensinada nas escolas, por meio de tratamentos preconceituosos, medidas discriminatórias, ofensas, constrangimentos, ameaças, agressões físicas ou verbais tem sido uma constante na vida escolar e profissional de jovens e adultos homossexuais.

Sobre um ato discriminatório no âmbito escolar que mais os tenha Ihe marcados, os entrevistados responderam:

Foram alguns meses depois que eu tinha assumido, eu estava em Cornélio ainda, e lá nos somos obrigados a fazer o desfile de sete de setembro envolvendo todas as escolas. [...] e eu era a madrinha do terceiro ano, estava desfilando na frente deles. Como eu trabalhei tão tranquilo, eu não pensei que poderia estar me expondo; [...] e ai ficamos sabendo depois, porque no momento não sabíamos, que alguém pagou um garoto para me humilhar durante o desfile, e depois da primeira e segunda quadra que eu desfilei, ele gritou "Sapatão!", e foi a primeira vez que ouvi essa palavra dirigida a mim, mas a principio eu não sabia realmente se estavam se dirigindo a mim [...] e uma quadra depois a pessoa gritou novamente e foi me seguindo repetindo aquilo em som alto, e como todo mundo sabia [...] Mais lá frente eu avistei o meu pai que estava assistindo o desfile, ai eu realmente fiquei preocupada, porque eu ser humilhada é uma coisa, mas os pais assistindo aquilo é outra. (Profa. Cristina)

Outro ponto a ser levantado por Rogério Diniz Junqueira e Louro seria a pedagogia do insulto, que se fundamentaliza a partir das piadas, brincadeiras, jogos, apelidos, insinuações e expressões desqualificantes, que são poderosos mecanismos de silenciamento e de dominação simbólica:

A escola configura-se, assim, como um espaço institucional de opressão, o que deve, ainda, à participação ou à omissão dos sistemas de ensino, da comunidade, das famílias, da sociedade, as instituições e do Estado. (JUNQUEIRA, 2009: 166)

Estes comentários e expressões pejorativas tornam-se uma agressão verbal. Podemos perceber a pedagogia do insulto, por exemplo, neste relato do professor Caio sobre um acontecimento na sala dos professores: uma vez na sala dos professores, eu fiquei um mês ali como professor, o professor de Matemática que era um dos donos da escola na verdade, contava muita piada na hora do intervalo, ali tinha jornal pra ler, tinha coisa pra fazer e o cara ficava contando piada. [...] E aí um dia começou a me estressar porque ele sempre contava duas, três de loira, de mulher, de português, de pobre e chegava de, alguma forma, às vezes uma de preto, às vezes uma de gay, era uma ou outra e um dia ele contou três, aí eu estourei e falei: "Olha professor, que as mulheres no recinto não se incomodem de ter o seu cérebro comparado com ervilhas, elas riem desse tipo de coisa, ok. Mas piada de preto e de viado você não vai contar na minha frente porque eu me 
incluo nas duas coisas." Foi aquele constrangimento geral, ele ficou vermeIho, enfiou a cara no jornal. [...] então eu o coloquei no lugar dele e a gente nunca mais conversou.

A professora também relata um momento de constrangimento aos comentários que aconteciam no cotidiano escolar:

eu lembro que na época que eu estava chegando em Londrina, estava passando a novela "Senhora do Destino", e durante a jornada pedagógica, eu me lembro dos comentários que faziam porque as meninas da novela haviam passado a noite juntas. Eram pessoas que hoje são duas grandes amigas, mas elas faziam comentários, que quando eu ia embora, eu chorava muito em casa; até porque eu não estava acostumada a ouvir aquele tipo de preconceito, principalmente porque são pessoas estudas neh!? Então aquilo me abalava bastante. (Profa. Cristina)

Para Louro, a escola é um dos espaços mais difíceis para os sujeitos assumirem sua condição de homossexual, pois, segundo a concepção heteronormativa:

só pode haver um tipo de desejo sexual e que esse tipo - inato a todos - deve ter como alvo um indivíduo do sexo oposto, a escola nega e ignora a homossexualidade (provavelmente nega porque ignora) e, dessa forma, oferece muito poucas oportunidades para que adolescentes ou adultos assumam, sem culpa ou vergonha, seus desejos. O lugar do conhecimento mantém-se, em relação à sexualidade, como o lugar do desconhecimento e da ignorância. (LOURO, 2001: 30)

A crença socialmente institucionalizada segundo a qual existiria apenas um modo legítimo de viver as masculinidades e as feminilidades e uma única forma "sadia e normal" de expressar-se sexualmente - a heterossexual - vem fazendo com que os sujeitos que não se enquadrem nessa representação sejam colocados e se sintam a margem, como "desviantes", "aberrações", "contra a natureza". É o que observa Fernando Seffner:

As múltiplas identidades construídas no campo da sexualidade (homens homossexuais, mulheres lésbicas, travestis, transgêneros, homens bissexuais, mulheres bissexuais etc.) pode se dizer que são identidades "complicadas", uma vez que marcadas como "desviantes", pois as identidades "nomeadas no contexto da cultura experimentam as oscilações e os embates da cultura: algumas gozam de privilégios, legitimidade, autoridade; outras são representadas como desviantes, ilegítimas, alternativas. Enfim, algumas identidades são tão "normais" que não precisam dizer de si; enquanto outras se tornam "marcadas" e, geralmente, não podem falar por si. (SEFFNER, 2006: 91-92) 
O Ministério da Educação diagnostica esta situação de violência a que são submetidos gays, lésbicas, travestis, transexuais e bissexuais e, entre as importantes questões que enfatiza em relação a esta temática na escola, destacamos:

Sexismoehomofobiaencontramnaexperiênciaescolarum dos seus mais decisivos momentos. A escola desempenha papel fundamental na construção, na introjeção, no reforço e na transformação das noções de masculinidade, feminilidade, heterossexualidade, homossexualidade, bissexualidade e transgeneridade e, por conseguinte, na formação identitária e na atuação das pessoas em todas as arenas da vida social. [...].

Entretanto, a escola é, ao mesmo tempo, um local privilegiado para a construção de uma consciência crítica e de desenvolvimento de práticas que se pautem pelo reconhecimento da diversidade e pelos direitos humanos [...]. Reside aí, portanto, a inquestionável importância de se promoverem ações sistemáticas que ofereçam as profissionais da educação bases conceituais e pedagógicas que melhor dotem de instrumentos para lidarem adequadamente com as diversidades de corpos, gêneros, identidades, sexualidades. (BRASIL, 2006:234)

Portanto, as narrativas aqui coletadas vão ao encontro do que o movimento homossexual brasileiro vem discutindo e debatendo sobre a invisibilidade desses sujeitos: "ainda se configura nas escolas brasileiras a invisibilidade dos sujeitos homossexuais que cotidianamente as ocupam". (ABGLT, 2006:48)

Os dispositivos pedagógicos têm atuado na constituição de normas discursivas que constituem modos da sexualidade a serem tratadas nas escolas, abordada segundo regras que controlam e legitimam os discursos autorizados, como o biológico, o da prevenção, o da reprodução:

São professores tímidos ou professores cujo movimento é agressivo, professores que se 'encapotam' todos, então é uma negação da presença corporal naquele espaço. [...] Se você não tem isso, e aí o que acontece: o corpo é pra sexo ou violência. As crianças mesmo, se um tocar no outro ou eles estão se batendo ou eles estão querendo fazer sexo, e essa é a abertura do outro olho, ou pior, é a abertura do olho do professor. (Prof. Caio)

Nos relatos constata-se haver na escola um cultivado e acentuado silenciamento em relação à homossexualidade, às pessoas homossexuais aos seus modos de viver. Um silenciamento produtor e reprodutor de outras falas, modos de ver e de agir. Institucionalmente, evita-se falar de respeito à diversidade sexual e continua-se, obstinada e ostensivamente, a ensinar e a incentivar que se pense e se aja de maneira a reprimir, marginalizar e estigmatizar as pessoas consideradas homossexuais.

Por fim, através de uma variedade de práticas sociais e técnicas de poder, produz-se e reproduzem-se discursos normativos sobre a sexualidade, classificando alguns casos como perversões sexuais, especialmente 
a homossexualidade. Desta forma, reafirma-se a homofobia em varias instâncias sociais, principalmente no cotidiano escolar.

A escola tem importante função no processo de conscientização, orientação e instrumentalização dos corpos da criança e do adolescente. A instituição escolar, ao classificar os sujeitos pela classe social, etnia e sexo, tem historicamente contribuído para re(produzir) e hierarquizar as diferenças. Essa tradição deixa à margem aqueles que não estão em conformidade com a norma hegemônica e, desta forma, não contempla a inclusão da diversidade sexual, tão discuta e proposta na atualidade.

\section{Considerações}

O senso comum, que perpassa toda nossa sociedade, através de idéias e comportamentos, não nos deixa ver e sentir, que nossas atitudes tão íntimas, mas tão inerentes a todo indivíduo, como a sexualidade e a maneira como nos relacionamos com os outros, nos tornam únicos, mas também iguais perante todo e qualquer humano.

O heterossexismo está tão arragaido na cultura, que se torna invisível em muitas de suas atitudes quase sutis, como por exemplo, em brincadeiras e piadas, como as presentes nas narrativas desta pesquisa. O universo escolar reproduz os preconceitos da sociedade e, na tentativa de evitar o convívio dos alunos heterossexuais, com pessoas homossexuais, faz da homossexualidade o maior alvo da discriminação. O risco dessa omissão esta presente nas falas dos professores aqui entrevistados, por começar com risinhos e insinuações, passando a assumir contornos mais graves, como os sentimentos de insegurança e humilhação, e por vezes, agressões físicas.

As desigualdades entre os sexos e a marginalização dos homossexuais acabam gerando vítimas de uma sociedade inacabada, de repressão, opressão e desinformação. Por fim, essa mesma sociedade está em constante afirmação dos preconceitos por meio, de uma conduta sócio-cultural discriminadora.

Acreditamos que a alternativa para eliminar a homofobia seria problematizar, isto é, estimular a reflexão a todo o momento em que a assimetria entre os gêneros e as diferentes orientações sexuais (heterossexuais, homossexuais e bissexuais) se manifestarem no cotidiano. A partir disso, vemos a importância da Educação Sexual, como oportunidade de assumirmos uma postura de igualdade e respeito entre os seres humanos, uma vez que, sim, acreditamos que as relações de gênero e a maneira de viver sua sexualidade, não devem ser pautadas em hierarquias de poder, mas no amor e na sensibilidade de ver o outro.

Entendemos que a educação sexual, no ambiente escolar, assume uma postura de alicerce para centralizar as discussões sobre diferenças, troca de informações, diálogos, debates, discussões; portanto, transcorre de forma imprescindível no desenvolvimento educacional, com a finalidade de que novas gerações possuam ter o direito a criticidade, autonomia e uma educação sexual. Além de oportunizar ao papel da escola, abrir espaço para 
que a pluralidade de concepções, valores e crenças sobre sexualidade possam se expressar.

A escola pode transformar-se em um lugar privilegiado para a promoção da igualdade de gênero e das orientações sexuais, oferecendo muitas possibilidades de debates sobre o tema. A inclusão da perspectiva de gênero e sexualidade no cotidiano escolar não pode ser eventual nem se limitar aos perigos, às doenças, à gravidez indesejada. Devemos envolver o coletivo de professores para que as estratégias sejam duráveis e sustentáveis e não, apenas ações restritas de alguns professores durante determinado período de tempo, nem de projetos isolados e de curta duração.

Ao corpo docente são as ações educativas continuadas que oferecerem possibilidades de elaboração das informações recebidas e de discussão dos obstáculos emocionais e culturais que impedem a adoção de condutas preventivas, autônomas e reflexivas referentes à sexualidade.

Para a inclusão da perspectiva da sexualidade, de gênero e diversidade sexual, devemos também re(analisar) e propor uma revisão curricular que inclua na formação dos docentes a aquisição de recursos para o enfrentamento das desigualdades de gênero, raça e etnia, orientação sexual, entre outras, permitindo que o coletivo de professores possa promover a igualdade e o respeito entre todos que compõem o cenário do ambiente escolar.

Temos também acesso aos Programas como o Brasil Sem Homofobia, cujo objetivo é sensibilizar os envolvidos na área da educação, já que as reações à sexualidade estão relacionadas a valores morais, religiosos e uma infinidade de aspectos subjetivos. Devemos levar não somente os educadores, mas sim, direção, auxiliares da secretária e trabalhadores que estão cotidianamente no universo escolar, a refletir sobre um tema, no caso a homossexualidade, que até então não se encontra presente na formação profissional.

Por meio das reflexões realizadas neste trabalho, entendemos que a escola nem sempre defenderá valores iguais aos das famílias, mas deverá oportunizar aos docentes, através da formação continuada, e aos alunos, por meio da educação sexual, contato com a diversidade social e sexual e refletir sobre o fato de que há pessoas diferentes, com valores diferentes e orientações sexuais diferentes, porém com direitos iguais.

Devemos abraçar a urgência por uma escola que seja livre de preconceitos, onde todos possam se expressar e se desenvolver plenamente, exercitando a capacidade de aceitação e compreensão das diferenças. Esse é o princípio do respeito à diversidade. O princípio de uma sociedade sem discriminações sociais e sexuais. O princípio da liberdade do ser humano.

O ambiente escolar deve fundamentalizar-se em um espaço e em uma educação menos desigual, mais humanizadora e que potencialize as habilidades humanas, até mesmo no modo de ver que há diferenças, mas reconhecer nelas e através delas as qualidades, vislumbres, edificações e dimensões que nos fazem grandes seres humanos. Únicos. Originais. Profundos. 


\section{Referências}

ASSOCIAÇÃO Brasileira de Gays, Lésbicas e Transgêneros (ABGLT). Resoluções do I Congresso da ABGLT: avanços e perspectivas. Curitiba: Associação Brasileira de Gays, Lésbicas e Transgêneros, 2006.

BRASIL. Ministério da Educação/Secad. Instruções para Apresentação e Seleção de Projetos de Formação de Profissionais da Educação para a Promoção da Cultura de Reconhecimento da Diversidade Sexual e da Igualdade de Gênero. Brasília: MEC, 2006. Disponível em <<www.portal.mec.gov.br/secad/ arquivos/pdf/resumo.pdf >>.

BRITZMAN, Deborah. O que é esta coisa chamada Amor - Identidade homossexual, educação e currículo. In: Revista Educação e Realidade. Vol. 21. pp. 71-96, jan/jun, 1996.

CANDAU, Vera Maria (Org.). Somos todos iguais? Escola, discriminação e educação em direitos humanos. Rio de Janeiro: DP\&A, 2003.

CONDE, Michelle Franco Conde. O Movimento Homossexual Brasileiro: sua trajetória e seu papel na ampliação do exercício da cidadania. Góias: Dissertação (Mestrado em Sociologia) - Universidade Federal de Goiás, 2004.

DINIS, Nilson Fernandes. Educação, relações de gênero e diversidade sexual. In: Educ. Soc. Campinas: vol. 29, n. 103, pp. 477-492, maio/ago. 2008. Disponível em <<www.cedes.unicamp.br $>>$.

FACCHINI, Regina. Sopa de Letrinhas? O movimento homossexual e produção de identidades coletivas nos anos de 1990. Rio de Janeiro: Garamond, 2005.

FACCO, Lúcia. Era uma vez um casal diferente: A temática na educação literária infanto-juvenil. São Paulo: Summus, 2009.

FRANCO, Neil. A diversidade entra na escola: Histórias de professores e professoras que transitam pelas fronteiras das sexualidades e do gênero. Uberlândia: Dissertação apresentada à Universidade Federal de Uberlândia, 2009.

FURLANI, Jimena. Educação sexual: Possibilidades didáticas. In: LOURO, Guacira Lopes (Org). Corpo, Gênero e Sexualidade. Petrópolis: Ed. Vozes. 2003.

JUNQUEIRA, Rogério Diniz (Org.). Diversidade Sexual na Educação: Problematizações sobre Homofobia nas escolas. Brasília: Ministério da Educação/ Secretária de Educação Continuada, Alfabetização e Diversidade/UNESCO, 2009.

LIONÇO, Tatiana, Diniz, Débora (Orgs). Homofobia e Educação: Um desafio ao Silêncio. Brasília: Letras Livres/Ed. Uniban, 2009.

LOURO, Guacira Lopes (Org.). O Corpo Educado: Pedagogias da sexualidade. Belo Horizonte: Ed. Autentica. 2001.

Gênero, Sexualidade e Educação. Petrópolis: Ed. Vozes. 1999.

Corpo, Gênero e Sexualidade. Petrópolis: Ed. Vozes. 2003.

MOTT, Luiz. Homossexualidade: Mitos e Verdades. Salvador: Ed. Grupo Gay da Bahia, 2003. 